\title{
Adsorptive behaviour of rutile phased titania nanoparticles supported on acid-modified kaolinite clay for the removal of selected heavy metal ions from mining wastewater
}

\author{
Mary Adejoke Ajala ${ }^{1,3,4} \cdot$ Ambali Saka Abdulkareem $^{1,3} \cdot$ Jimoh Oladejo Tijani ${ }^{2,3} \cdot$ Abdulsalami Sanni Kovo $^{1,3}$
}

Received: 9 August 2021 / Accepted: 16 December 2021 / Published online: 28 January 2022

(c) The Author(s) 2022

\begin{abstract}
This study investigated the removal of metal ions pollutants in mining wastewater such as $\mathrm{Mn}$ (II), $\mathrm{Fe}$ (III), $\mathrm{Pb}$ (II) and $\mathrm{Cu}$ (II) ions by acid-activated kaolinite clay (AAC) and titanium (IV) oxide $\left(\mathrm{TiO}_{2}\right)$ nanoparticles supported on the $\mathrm{AAC}\left(\mathrm{TiO}_{2}-\mathrm{AAC}\right)$. $\mathrm{TiO}_{2}$ nanoparticles were synthesised using titanium salt precursor with leaves extract of Parkia biglobossa and impregnated on the $\mathrm{AAC}$ to develop $\mathrm{TiO}_{2}-\mathrm{AAC}$ as a nanoadsorbent. The $\mathrm{AAC}$ and $\mathrm{TiO}_{2}-\mathrm{AAC}$ nanocomposites were characterized using different analytical techniques. Actual concentrations of selected heavy metals in mining wastewater was determined prior and after treatment using the prepared adsorbents in batch adsorptive studies with atomic absorption spectrophometer. The characterisation studies confirmed that a rutile phase $\mathrm{TiO}_{2}$ was doped the on acid-activated kaolinite clay. Morphology analysis shows that the developed adsorbents were homogeneously dispersed and porous. The results of the surface area further revealed that the $\mathrm{AAC}, \mathrm{TiO}_{2}$ and $\mathrm{TiO}_{2}-\mathrm{AAC}$ has $14.15,10.23$ and $32.98 \mathrm{~m}^{2} / \mathrm{g}$, respectively. The percentage removal of heavy metals followed the order of $\mathrm{TiO}_{2}-\mathrm{AAC}>\mathrm{AAC}$ due to the higher surface area and enhanced surface functionality of the former than the latter. The adsorption capacity increased from 86.13 to $91.99 \%$ (Fe (III)), 83.12 to $89.37 \%$ (Mn (II)), 68.48 to $81.95 \%$ ( $\mathrm{Cu}$ (II)) and 29.49 to $32.39 \%$ ( $\mathrm{Pb}$ (II)) from $\mathrm{AAC}$ to $\mathrm{TiO}_{2}-\mathrm{AAC}$. The kinetic and isotherm models were best fitted by pseudo-second-order kinetics and Langmuir model. Whilst the thermodynamic investigation found that, the adsorption process was endothermic, spontaneous and chemisorption controlled. Conclusively, the $\mathrm{TiO}_{2}-\mathrm{AAC}$ nanocomposite exhibited better performance than AAC alone.
\end{abstract}

Keywords Mine site $\cdot$ Manganese $\cdot$ Lead $\cdot$ Titanium (IV) oxide $\cdot$ Isotherm $\cdot$ Kinetics $\cdot$ Adsorption technology

\section{Introduction}

The challenges posed by urbanisation and industrialisation are humongous. Among these is water pollution, which endangers the survival of both plants and animals in the

Mary Adejoke Ajala

ajala.ma@unilorin.edu.ng

1 Department of Chemical Engineering, Federal University of Technology, Minna, Niger State, Nigeria

2 Department of Chemistry, Federal University of Technology, Minna, Niger State, Nigeria

3 Nanotechnology Research Group, Centre for Genetic Engineering and Biotechnology (CGEB), Federal University of Technology, Niger State, P.M.B 65, Minna, Niger State, Nigeria

4 Department of Chemical Engineering, University of Ilorin, Ilorin, Kwara State, Nigeria present twenty-first century due to exposure to different contaminants. Toxic pollutants of several types are being released into the water bodies causing considerable damages to the human organs, plants and distortion of the ecosystem (Manisalidis et al. 2020; Redha et al. 2021). These pollutants are released as by-products from the operations of metallurgy, electroplating, painting, pharmaceutical and mining industries (Wang et al. 2021). Mining, as an economic activity has contributed greatly to the GDP growth of several countries (Acheampong and Ansa 2017; Wang et al. 2021) however there is an attendant challenge of pollution especially the release of wastewater containing heavy metals causing severe damage to the water resources (Saha and Sinha 2018). Heavy metals which includes $\mathrm{Mn}, \mathrm{Pb}, \mathrm{Ni}$, $\mathrm{Fe}, \mathrm{Cu}, \mathrm{Cd}, \mathrm{Cr}$ with other physicochemical parameters like; turbidity, sulphate, phosphate, nitrate, COD, BOD are the major characteristics of an abandoned mining site wastewater (Bwapa et al. 2017; Ojonimi et al. 2019). Exposure to 
these contaminants is the major cause of infirmities, diseases and dysfunctions both in plants and animals (Balali-Mood et al. 2021). Lead $(\mathrm{Pb})$ as a heavy metal has been reported to cause mental retardation, hyperactivity, kidney damage, dermatitis, encephalopathy and cardiovascular dysfunctions (Balali-Mood et al. 2021). Exposure to Cd causes lungs cancer and birth defects (Wang et al. 2021). Chromium exposure can cause skin epidemics, respiratory complications, severe renal failure, debilitated immune systems, kidney and liver impairment, alteration of genetic material, lung cancer, respiratory fibrosis (Pavesi and Moreira 2020). Nickel can also cause lungs, nose and bone cancer, dizziness, headache, queasiness and vomiting, chest pain, rapid respiration (Lakherwal 2014). Other effect includes: liver cirrhosis, thyroid dysfunction, skin peels, diarrhoea, stunted growth, lower reproduction rate, bioaccumulation in food chain, death of organisms and distortion of the ecosystem (Balali-Mood et al. 2021; Wang et al. 2021). Thus, there is urgent need to treat mining wastewater prior to release into the environment.

Conventional wastewater treatment techniques such as filtration (Bhateria and Singh 2019), chemical oxidation (Oh et al. 2020), ion exchange (Zhao et al. 2019), ozonation (Prasse et al. 2015), flocculation, electro-coagulation (Fu et al. 2019), reverse osmosis, electrodialysis, precipitation, co-precipitation flocculation, (Bijang et al. 2020) have been employed to treat complex industrial wastewater such as mining wastewater. These techniques have certain limitations such as the high cost of reagents, generation of toxic sludge, high post-treatment cost, occupation of space, high energy requirements, and failure to remove heavy metals in the range of 1-100 $\mathrm{mg} / \mathrm{L}$ amongst others (Gholipour et al. 2020). On the contrary, adsorption technology shows exceptional characteristics such as simplicity in design, cost-effectiveness, eco-friendly and high removal efficiency especially when heavy metals concentration in wastewater ranges from 1 to $100 \mathrm{mg} / \mathrm{L}$ (Yang et al. 2019; Subhi et al. 2020).

Several adsorbents like activated carbon (Egbosiuba et al. 2019; Shukla et al. 2020), date seed activated carbon: (Subhi et al. 2020), Turmeric/polyvinyl alcohol Th(IV) phosphate electrospun fibers (Ahamed et al. 2016), clays, zeolites, alumina, polymeric materials (Ahamed et al. 2016; Khan et al. 2019; Pietrelli et al. 2019) and nanomaterials have been used by diverse researchers to impound heavy metals from wastewater (Siddiqui and Chaudhry 2017). Amongst nanomaterials widely employed for environmental remediation are metallic and metal oxide nanoparticles like titanium dioxide, zinc oxide, tungsten oxide, iron oxide, silicon oxide nanoparticles to mention but a few (Guillaume et al. 2018; Guo et al. 2013; Liu et al. 2015; Yang et al. 2019). $\mathrm{TiO}_{2}$ nanoparticles are widely investigated by researchers due to their photochemical, thermal and biological stability, low cost, low toxicity, great refractive index, excellent antimicrobial and adsorptive properties amongst others (Durango-Giraldo et al. 2019; Landage et al. 2020). Titanium (IV) oxide exists as anatase, brookite or in the rutile phase with the anatase phase unstable and most suitable for photocatalytic applications (Musial et al. 2020; Tijani et al. 2019). Studies have shown that most biological synthesised $\mathrm{TiO}_{2}$ are anatase phase or mixed $\mathrm{TiO}_{2}$ phases and are commonly used for photocatalytic applications (Krishnan and Mahalingam 2017; Mustapha et al. 2020) while $\mathrm{TiO}_{2}$ in the rutile phase is employed as an adsorbent because of thermal stability and presence of more anchoring sites to sequester adsorbate in the aqueous medium. Rutile $\mathrm{TiO}_{2}$ has also been reported to have reduction kinetics of 2.5 times faster than anatase $\mathrm{TiO}_{2}$, depicting an improved activity (Oi et al. 2016). Despite the advantages of $\mathrm{TiO}_{2}$ nanoparticles, it agglomerates when dispersed in aqueous medium, this affects its surface area and pose challenges to recover due to the nanocrystalline size, which seriously limits its practical application (Akinnawo 2019). To prevent the agglomeration, improve postseparation from wastewater and ensure the stability of $\mathrm{TiO}_{2}$ nanoparticles, modification by a metal-organic framework, functionalization based on doping mechanism, on supports materials have been identified as a viable alternative (Falk et al. 2018; Madadi et al. 2020; Rodríguez-Padrón et al. 2019). Materials such as $\mathrm{MgO}, \mathrm{Al}_{2} \mathrm{O}_{3}$, graphite, zeolite, carbon nanotubes, furacene and clay have been used to support $\mathrm{TiO}_{2}$ and other metal oxides to solve post-separation problems (Khan et al. 2019; Krishnan and Mahalingam 2017; Ouyang et al. 2019; Youssef et al. 2015). Kaolinite clay have efficient removal capacity aimed at heavy metal ions through the ion exchange process (Mustapha et al. 2019). To achieve this, the unwanted metal ions become confined to the clay through, electrostatic force of attraction amid the metal ions in solution and the anionic surfaces on the clay particles in the adsorption process (Abdallah 2019). Other desirable properties of kaolinite clay in adsorption are; cation exchange ability, non-toxicity, cheap costs, ecofriendly and availability.

Kaolinite clays have been used for wastewater treatment especially, metal ion removal in aqueous wastewaters. Saudi natural clay was applied for $\mathrm{Ni}$ and $\mathrm{Cd}$ adsorption from an aqueous solution and the research established the efficiency of the clay for adsorption applications (Khan et al. 2019). Clay without modification was also used for successful adsorption of $\mathrm{Cu}$ and $\mathrm{Pb}$ from simulated wastewater (Budsaereechai et al. 2012). Modified and unmodified kaolinite clay was used by Al-Essa and Khalili (2018) for treating wastewater. Mungondori et al. (2017) made use of clay composite without chemical modification for the removal of selected heavy metal ions from simulated wastewater. In addition, $\mathrm{TiO}_{2}, \mathrm{TiO}_{2} / \mathrm{SiO}, \mathrm{TiO}_{2}$ /bentonite clay was also used for the removal of pollutants in wastewater but, most of these adsorbents were unmodified with acid and the obtained 
phase of $\mathrm{TiO}_{2}$ not rutile phase of titania (Ashraf et al. 2019; Cardoso et al. 2019; Krishnan and Mahalingam 2017). There is therefore, paucity of information on the use of green synthesised rutile titanium (IV) oxide nanoparticle supported on acid activated clay for the removal of heavy metal from mine site wastewater. The present study, hitherto, focused on the green synthesis of rutile-phase titanium nanoparticles using Parkia biglobossa leaves extract, immobilised on acid activated kaolinite clay for the comparative adsorption studies of selected heavy metals from deleterious mining wastewater onto the activated clay (AAC) and titanium (IV) oxide immobilised on activated clay $\left(\mathrm{TiO}_{2}-\mathrm{AAC}\right)$.

\section{Materials and method}

Titanium (IV) isopropoxide, sodium hydroxide, hydrochloric acid and tetra Oxo sulphate (IV) acid having percentage purity in the range of 95-99.8\% were obtained from SigmaAldrich. The chemicals used were of analytical grade and used as received without further purification.

The fresh leaves of Locust bean (Parkia biglobossa) were obtained from different locations in Ilorin, Kwara State (Nigeria) Metropolis. A plant Taxonomist at the department of Plant Biology, University of Ilorin, Ilorin, Kwara State, Nigeria, identified the leaves. Local clay was collected from clay deposits in Akerebiata, Ilorin, while mining wastewater was collected from the Chanchaga, Chanchaga Local government Area, Minna, Niger State, Nigeria.

\section{Pre-treatment and preparation of plant extract}

The locust bean leaves were washed with distilled water, dried at ambient temperature in the laboratory for 14 days. To prepare the plant extract, $5 \mathrm{~g}$ of the pulverised leaves were weighed into a $250 \mathrm{~mL}$ beaker, followed by the addition of $0.1 \mathrm{~L}$ of deionised water. The mixture was stirred and heated at $70{ }^{\circ} \mathrm{C}$ for $15 \mathrm{~min}$ using a magnetic stirrer, and later allowed to cool to room temperature. Then, filtered using Whatman No. 1 filter paper and the filtrate (aqueous leaves extract) was stored in a refrigerator at $4{ }^{\circ} \mathrm{C}$.

\section{Beneficiation and Acid activation of nanoclay}

The raw clay was beneficiated by sedimentation technique to obtain a fraction of $<300 \mathrm{~mm}$ particle size. This was done by weighing $250 \mathrm{~g}$ of milled clay sample in a petri dish; the weighed clay was dispersed into containers containing $5000 \mathrm{~mL}$ of distilled water and stirred. The mixture was allowed to stay for $24 \mathrm{~h}$ for proper intercalation of the clay structure by water molecules, then sieved with a $300 \mathrm{~mm}$ sieve diameter. The sieved clay was allowed to settle in containers and the settling time of the clay was obtained using the Eq. (1).

$r^{2}=\frac{9 \mu h}{2\left(\rho_{1}-\rho_{2}\right) g t}$

where $r=$ particle size (radius) of clay, assumed to be spherical, $\mu=$ viscosity of distilled water, $h=$ settling height of fluid, $g=$ gravitational acceleration, $\rho_{1}=$ clay density, $\rho_{2}=$ water density, and $t=$ settling time

The settled clay was decanted, sun-dried and dried in the oven at $100^{\circ} \mathrm{C}$ for $1 \mathrm{~h}$ to obtain a constant weight. The dried clay was pulverised with an industrial pulveriser, then sieved with $250 \mathrm{~mm}$ diameter sieve, to obtain beneficiated clay.

\section{Acid-activation of beneficiated kaolinite clay}

The acid activation of beneficiated kaolinite clay was carried out as follows: $50 \mathrm{~g}$ of beneficiated clay was weighed into a $500 \mathrm{~mL}$ beaker, followed by the addition of $150 \mathrm{~mL}$ of deionised water. The mixture was stirred to form a homogeneous solution and $100 \mathrm{~mL}$ of $98 \%$ concentrated $\mathrm{H}_{2} \mathrm{SO}_{4}$ was added and stirred at $200 \mathrm{rpm}$ for $2 \mathrm{~h}$ to prevent the content from forming mud. Thereafter, the slurry was allowed to age for $3 \mathrm{~h}$; then washed severally with de-ionised water until a $\mathrm{pH}$ of 7 was attained and subsequently filtered. The sediment was oven-dried at $100{ }^{\circ} \mathrm{C}$ for $2 \mathrm{~h}$ to remove residual water and then pulverised, then coded as AAC and kept in a sample bottle.

\section{Green synthesis of titanium (IV) oxide nanoparticles}

The synthesis of $\mathrm{TiO}_{2}$ nanoparticles was carried out using the modified method described by Tijani et al. (2019) and Zahir et al. (2015). A known volume $\left(50 \mathrm{~cm}^{3}\right)$ of Parkia biglobossa aqueous leaves extract was measured into a $250 \mathrm{~mL}$ beaker followed by slowed addition of $50 \mathrm{~cm}^{3}$ of $0.1 \mathrm{M}$ titanium (IV) isopropoxide under continuous stirring on a magnetic stirrer at $2000 \mathrm{rpm}$ for $2 \mathrm{~h}$. The $\mathrm{pH}$ of the mixture was adjusted to 8 using $1 \mathrm{M} \mathrm{NaOH}$ solution. The colour changed was accompanied with the formation of precipitates. The $\mathrm{TiO}_{2}$ nanoparticles formed were filtered, washed severally with distilled water and allowed to age overnight. The $\mathrm{TiO}_{2}$ cake was oven-dried at $70{ }^{\circ} \mathrm{C}$ for $1 \mathrm{~h}$ followed by calcination in a muffle furnace at $550{ }^{\circ} \mathrm{C}$ for $2 \mathrm{~h}$.

\section{Preparation of Titanium (IV) oxide doped acid-activated kaolinite clay nanocomposite}

$\mathrm{TiO}_{2}$ /activated kaolinite clay nanocomposites were prepared by wet impregnation method: $2.5 \mathrm{~g}$ of the $\mathrm{TiO}_{2}$ nanoparticles prepared were dispersed in $50 \mathrm{~mL}$ of distilled water and $20 \mathrm{~g}$ of activated kaolinite clay was added, the mixture was stirred 
at $200 \mathrm{rpm}$ for $2 \mathrm{~h}$. The resulting slurry was allowed to age for $12 \mathrm{~h}$, oven dried at $70{ }^{\circ} \mathrm{C}$ for $2 \mathrm{~h}$ and then calcined in a muffle furnace at $550{ }^{\circ} \mathrm{C}$ for $2 \mathrm{~h}$ and the powdered titanium (IV) oxide supported activated clay nanocomposite obtained was coded $\left(\mathrm{TiO}_{2}-\mathrm{AAC}\right)$.

\section{Characterisation of the synthesised titanium dioxide}

The UV-Visible absorption spectrophotometry analysis was done to determine the absorption wavelength of the $\mathrm{TiO}_{2}$ nanoparticles using the UV-SPECTROMETER, (UV1800, SHIMADZU, Japan). The crystal composition/phase of the titanium (IV) oxide-based material was determined by X-ray diffraction (Bruker AXS D8 X-Ray Machine with $\mathrm{CuK} \alpha$ radiation) and the crystallite size calculated using the Scherer equation (Eq. 2).

$D=\frac{K \lambda}{\mathrm{B} \operatorname{Cos} \theta}$

where $\lambda=$ wavelength of X-ray.

$K=$ Scherer's constant (0.9).

$B=$ Full Width at Half maximum (FWHM).

$\theta=$ diffraction angle.

$D=$ Average crystallite size.

The functional groups in the materials were identified using Perkin Elmer 100 FT-IR spectrometer model "two". High-resolution scanning electron microscopy (Zeiss Auriga HRSEM) was used for the determination of the morphology of the particles. The surface area and pore size and pore volume of the samples were determined using the Brunauer, Emmet and Teller (BET) Nitrogen adsorption procedure on NOVA 4200e model equipment. The samples were degassed at $200{ }^{\circ} \mathrm{C}$ for $2 \mathrm{~h}$ under inert nitrogen gas flow, to remove adsorbed moisture and organic compounds that may block the pores. While X-ray photoelectroscopy (XPS) model (PHI 5400 XPS spectrometer); with a non-monochromatic (Mg $\mathrm{K} \alpha) \mathrm{X}$-ray source was used to determine the surface oxidation states of the elements in the composite materials.

\section{Batch adsorption behaviour of $\mathrm{AAC}$ and $\mathrm{TiO}_{2}-\mathrm{AAC}$}

The batch adsorption experiments for the removal of $\mathrm{Mn}$ (II), $\mathrm{Fe}$ (III), $\mathrm{Pb}$ (II) and $\mathrm{Cu}$ (II) ions from mining wastewater onto activated kaolinite clay (AAC) and activated kaolinite clay- $\mathrm{TiO}_{2}\left(\mathrm{AAC}-\mathrm{TiO}_{2}\right)$ were performed based on the variation of contact time (20-180 $\mathrm{min})$, adsorbent dose (0.1-1.0 g), and temperature $\left(30-70{ }^{\circ} \mathrm{C}\right)$. A thermostatic water bath shaker (Pye Unicam SP-9 Cambridge, UK) was utilised to carry out the adsorption experiments and the stirring speed was maintained at $200 \mathrm{rpm}$ for all experiments. The effect of each parameter on the removal efficiency of the selected heavy metals from mining wastewater is described as follows.

\section{Effect of contact time}

The effect of contact time on the rate of removal of $\mathrm{Mn}$ (II), $\mathrm{Fe}$ (III), $\mathrm{Pb}$ (II) and $\mathrm{Cu}$ (II) by the $\mathrm{AAC}$ and $\mathrm{AAC}-\mathrm{TiO}_{2}$ can be described as follows: $100 \mathrm{~cm}^{3}$ of mining wastewater was measured into a $200 \mathrm{~mL}$ conical flask, $0.5 \mathrm{~g}$ each of AAC and $\mathrm{TiO}_{2}$-AAC was weighed and added into the wastewater. The flasks were prepared in duplicates, covered and then placed in the thermostatic water bath shaker maintained at $30{ }^{\circ} \mathrm{C}$ and $200 \mathrm{rpm}$ for the diverse contact times (20, 40, $60,80,100,120,140,160$ and $180 \mathrm{~min}$ ). After each contact time, the samples were withdrawn from the flask, filtered and the filtrate was analysed using Atomic Absorption Spectrophotometer (AAS) (PG990 model). The quantity of each of the metal ion adsorbed was calculated using Eq. (3), adsorption at equilibrium was calculated using Eq. (4) while the percentage removal was calculated with Eq. (5).

\section{Effect of adsorbent dosage}

The influence of adsorbent dosage on the removal efficiency of $\mathrm{Mn}$ (II), $\mathrm{Fe}$ (III), $\mathrm{Pb}$ (II) and $\mathrm{Cu}$ (II) from mining wastewater was determined by the addition of varied quantities of the activated clay and $(0.1,0.2,0.3,0.4,0.5,0.6,0.7,0.8,0.9$ and $1.0 \mathrm{~g}$ ) into $0.1 \mathrm{~L}$ of the mining wastewater in a $200 \mathrm{~mL}$ conical flask. The covered flask was placed in the thermostatic water bath shaker set at $30^{\circ} \mathrm{C}$ while sustaining a constant contact time (120 min). After $120 \mathrm{~min}$ of the adsorbate interaction with the adsorbent, the solution was filtered and the filtrate was analysed with the AAS. The amount of each metal ion removed was also calculated using Eq. (5).

\section{Effect of temperature}

The temperature influence on the heavy metal ions adsorbed was investigated by adding $0.5 \mathrm{~g}$ of the adsorbent to $0.1 \mathrm{~L}$ of the mining wastewater in a $200 \mathrm{~mL}$ conical flask. The flasks were made in duplicates, then placed in the thermostatic water bath shaker. The flasks were carefully covered and the temperature varied to $30,40,50,60$ and $70^{\circ} \mathrm{C}$ using equilibrium contact time (120 min). Sampling was done at the end of $120 \mathrm{~min}$, followed by filtration using Whatman No. 1. Filter paper. Then, the filtrates were examined for the selected heavy metals using AAS.

\section{$\mathrm{pH}$ point of zero charges $\left(\mathrm{pH}_{\mathrm{PZC}}\right)$ determination for $\mathrm{AAC}$ and $\mathrm{AAC}-\mathrm{TiO}_{2}$}

The $\mathrm{pH}$ point of zero charges (pHPZC) of the two materials, which is conveyed as the electrical balance between 
the adsorbent surface and metal ion adsorbate solution was determined. $0.1 \mathrm{~L}$ of mining wastewater was measured into 12 separate Erlenmeyer flasks (in duplicates), the initial $\mathrm{pH}$ $\left(\mathrm{pH}_{i}\right)$ was measured in the range of 2-12 (at 2.0 intervals) for the different flasks. Few drops of $2.0 \mathrm{M}$ of $\mathrm{HCl}$ or $\mathrm{NaOH}$ was added to the mixture to control the $\mathrm{pH}$ of the solution using a pH meter (Eutech Instruments, Model Ecoscan Singapore). The determined optimum dosage (5 g) of AAC and $\mathrm{TiO}_{2}-\mathrm{AAC}$ was added into 12 flasks separately, afterwards arranged on a shaker for $48 \mathrm{~h}$ in order to achieve balance charges between the surface of the adsorbent and the wastewater. The suspension was filtered after $48 \mathrm{~h}$ and the final $\mathrm{pH}$ at equilibrium $\left(\mathrm{pH}_{f}\right)$ of the filtrate was recorded. $\mathrm{The}_{\mathrm{pH}} \mathrm{PZC}$ of each adsorbent represents the meeting point between the $\mathrm{pH}_{i}$ curve against $\mathrm{pH}_{f}$ curve. The technique was repeated for AAC to determine its point of zero $\mathrm{pH}$ charge as well.

\section{Data analysis}

The amount of each metal ion (Mn (II), Fe (III), Pb (II) and $\mathrm{Cu}$ (II)) adsorbed at equilibrium was calculated by using Eq. 3:

$q_{t}=\frac{\left(C_{o}-C_{t}\right) V}{m}$

While, the adsorption at equilibrium, $q_{e}(\mathrm{mg} / \mathrm{g})$, was analysed using Eq. 4:

$q_{e}=\frac{\left(C_{o}-C_{e}\right) V}{m}$

And the percentage of metal ion removal was calculated using Eq. 5 (Guillaume et al. 2018):

$\operatorname{Removal}(\%)=\frac{C_{o}-C_{t}}{C_{o}} \times 100 \%$

where $C_{o}$ is the initial concentration, $C_{t}$ is concentration at time $t$, and $C_{e}$ is the equilibrium metal ion concentration $(\mathrm{mg} / \mathrm{L})$ respectively. $V$ represents the water sample volume $(\mathrm{L}), m$ is the mass $(\mathrm{g})$ of adsorbent used and $q_{e, t}(\mathrm{mg} / \mathrm{g})$ is the adsorption capacity of metal ion adsorbed per gram of the adsorbent at equilibrium.

\section{Kinetic study}

The adsorption kinetics of $(\mathrm{Mn})$, Iron $(\mathrm{Fe}), \mathrm{Lead}(\mathrm{Pb})$ and Copper $(\mathrm{Cu})$ metal ions onto $\mathrm{AAC}$ and $\mathrm{AAC}-\mathrm{TiO}_{2}$, were analysed using four kinetic models namely; pseudo-firstorder (PFO) (Miyah et al., 2017), pseudo-second-order (PSO) (Ho and McKay, 1999), intraparticle diffusion and Elovich kinetic model (Boparai et al., 2011). The PFO model is expressed mathematically as shown in Eq. 6 : $\ln \left(q_{\mathrm{e}}-q_{t}\right)=q_{\mathrm{e}}-k_{1} t$

The PSO model is shown in Eq. 7:

$\frac{d q_{t}}{d t}=k_{2}\left(q_{\mathrm{e}}-q_{t}\right)^{2}$

Also, $q_{\mathrm{e}}(\mathrm{mg} / \mathrm{g})$ is the adsorption capacity of metal ion adsorbed per gram of the adsorbent at equilibrium, while $\mathrm{q}_{\mathrm{t}}$ is the adsorbed phase at a time, $t$.

The intraparticle diffusion model is expressed by the relationship presented in Eq. 8:

$q_{t}=K_{p} t^{1 / 2}+C_{p}$

The Elovich kinetic model is as presented in Eq. 9:

$q_{t}=\frac{1}{\beta} \ln (\alpha \beta)+\frac{1}{\beta} \ln t$

where $q_{e}(\mathrm{mg} / \mathrm{g})$ is the adsorbed quantity of metal ion at equilibrium, $q_{t}(\mathrm{mg} / \mathrm{g})$ is the adsorbed amounts of each metal ion at time $t(\mathrm{~min}), k_{1}\left(\mathrm{~min}^{-1}\right), k_{2}(\mathrm{mg} / \mathrm{g} \mathrm{min}), k_{\mathrm{int}}$ $\left(\mathrm{mg} / \mathrm{g} \min ^{1 / 2}\right)$ and $\alpha(\mathrm{mg} / \mathrm{g}$ min) are; pseudo-first order, pseudo-second order, intraparticle diffusion and Elovich rate constants. $C(\mathrm{mg} / \mathrm{g})$ equals the constant for the boundary layer thickness, while $\beta(\mathrm{mg} / \mathrm{g} \mathrm{min})$ represents the constant for the desorption rate relative to the activation energy for surface coverage extent and chemisorption process.

\section{Adsorption isotherm model}

Different adsorption isotherm models were applied to evaluate the distribution of adsorbate molecules at the solid/ liquid interface. The equilibrium adsorption data obtained were analysed using Langmuir (Langmuir 1918), Freundlich (Miyah et al. 2017), Temkin (Egbosiuba et al. 2019) and Dubinin-Radushkevich (D-R) (Ayawei et al. 2017; Dubinin 1969) models to show metal ions adsorption onto the surface of the AAC and $\mathrm{AAC}-\mathrm{TiO}_{2}$.

The mathematical representation of the Langmuir isotherm model is given by Eq. (9):

$\frac{C_{e}}{q_{e}}=\frac{1}{q_{o} K_{L}}+\frac{C_{e}}{q_{o}}$

where $q_{e}(\mathrm{mg} / \mathrm{g})$ is the amount of metal ion uptake at equilibrium, $q_{m}(\mathrm{mg} / \mathrm{g})$ represents maximum adsorption capacity for monolayer coverage on the surface of the adsorbent. $C_{e}$ $(\mathrm{mg} / \mathrm{L})$ represents metal ions concentration at equilibrium while $k_{L}(\mathrm{~L} / \mathrm{mg})$ is the Langmuir equilibrium adsorption constant.

Freundlich isotherm model equation is given in Eq. 11: 
$\ln q_{e}=\ln K_{F}+\frac{1}{n F} \ln C_{e}$

where $K_{F}$ in $\mathrm{mg} / \mathrm{g}$ and $n_{F}$ is the Freundlich adsorption isotherm constant which denotes the adsorption capacity of the AAC and the heterogeneity of the adsorption process, respectively.

Temkin isotherm model equation is presented in Eq. 12:

$q_{e}=\frac{R T}{b_{T}} \ln A_{T}+\frac{R T}{b_{T}} \ln C_{e}$

where $A_{T}(\mathrm{~L} / \mathrm{g})$ and $b_{T}(\mathrm{~kJ} / \mathrm{mol})$ are Temkin constants, associated with the heat of adsorption and maximum binding energy. $T\left({ }^{\circ} \mathrm{C}\right)$ is the temperature, while $R(8.314 \mathrm{~J} / \mathrm{mol} . \mathrm{K})$ is the universal gas constant.

$D-R$ model is also represented in Eq. 13 as:

$\ln q_{e}=\ln q_{o}-K_{a d} \varepsilon^{2}$

where $q_{a d}$ is a constant related to adsorption mean free energy and $q_{s}$ is the $D-R$ adsorption capacity at monolayer saturation, while $\varepsilon$ is called Polanyi potential.

\section{Adsorption thermodynamics}

The thermodynamics studies of $\mathrm{Mn}, \mathrm{Fe}, \mathrm{Pb}$ and $\mathrm{Cu}$ ions adsorption onto $\mathrm{AAC}$ and $\mathrm{AAC}-\mathrm{TiO}_{2}$ were carried out at temperatures; 30, 40, 50, 60 and $70{ }^{\circ} \mathrm{C}$, respectively. This was carried out to know the influence of temperature on the removal efficiency of the metal ions from wastewater. Change in enthalpy $\left(\Delta \mathrm{H}^{\circ}\right)$, change in Gibbs free energy $\left(\Delta G^{\circ}\right)$ and entropy change $(\Delta S)$ of the system during the adsorption process were evaluated with Eq. (14)-(17)

$\Delta G_{a d s}=\Delta G^{\circ}+R T \ln Q$

The change in Gibbs free energy $(\Delta \mathrm{G}, \mathrm{kJ} / \mathrm{mol})$ of the metal ion(s) adsorption progression was determined by Eq. (13) where $\mathrm{Q}$ designates the quotient of reaction, and relate to the metal ion concentrations of a system that is not in equilibrium. But, at equilibrium $\Delta G_{\mathrm{ads}}=0$ making Eq. (14) reduced to Eq. (15)

$\Delta G^{\circ}=-R T \ln K d$

where

$K d=\frac{q_{e}}{C_{e}}$

$\ln K_{d}=-\frac{\Delta G^{0}}{R T}=\frac{\Delta S}{R}-\frac{\Delta H^{0}}{R T}$

where $K_{d}$ is the equilibrium parameter signified by Eq. (16), $q_{e}$ and $C_{e}$ are the quantity of metal ion adsorbed and the concentration of each metal ion in the solution at equilibrium.
The $\Delta H^{\circ}$ and $\Delta S^{\circ}$ values were obtained from the slope and intercept of the Van't Hoff plots of In $K_{d}$ against $1 / T$ given in Eq. 17 (Bankole et al. 2019).

\section{Analysis of error}

To remove or minimise error in the data obtained from the figures of each experiment, analysis were duplicated and subjected to statistical analysis. The constants from the isotherm and kinetics studies were determined using Origin pro (2019a) software at a very high accuracy level. The linear determination coefficient $\left(R^{2}\right)$, the non-linear Chi-square test $\left(X^{2}\right)$ and the sum of square error (SSE) tests were performed to further choose the best-fitted isotherm and kinetic models. The mathematical equations are given in Eqs. 18 and 19:

$X^{2}=\sum\left(\left(q_{e, \exp }-q_{e, \mathrm{cal}}\right)^{2} / q_{e, \mathrm{cal}}\right)$

$\mathrm{SSE}=\sum\left(q_{e, \exp }-q_{e, \text { cal }}\right)^{2}$

\section{Results and discussion}

\section{Phytochemical analysis of plant leaves}

The collected plant leaves of Parkia biglobossa L. were assessed for their phytochemical constituents using the standard analytical methods and the result is presented in Table 1. It was observed that the Parkia biglobossa L. leaves have a considerable amount of phytochemical contents of Phenols, Flavonoids and Tannins. Studies have shown that these three phytochemicals contents are responsible for the stabilization and capping of metal oxide nanoparticles. The result is indicative of the fact that Parkia biglobossa leaves can be used for the synthesis of the nanoparticles. The confirmed phytochemicals present are in agreement with the findings of Dedehou et al. (2016) and Yusof et al. (2018).

Table 1 Phytochemical analysis of P. biglobossa leaves

\begin{tabular}{ll}
\hline Phytochemicals & Interference \\
\hline Tannin & + \\
Flavonoids & + \\
Phenol & + \\
Steroids & + \\
Phlobatannins & - \\
\hline
\end{tabular}

Key (+) present (-) absent 


\section{UV-visible spectroscopic analysis of $\mathrm{TiO}_{2}$ nanoparticles}

During the synthesis of titanium oxide nanoparticles, colour changes from greenish-brown of the leaf extract to a light brown solution were observed. This effect is called Tyndall effect which indicates the formation of nanoparticles in the solution (Soni et al. 2018). UV-visible spectrophotometer spectra of the synthesized titanium (IV) oxide nanoparticles is shown in Fig. 1. The figure revealed the presence of an absorption band at $358 \mathrm{~nm}$. The band obtained is relatively close to $350 \mathrm{~nm}$ reported in the literature (Swathi et al. 2019), where $\mathrm{TiO}_{2}$ nanoparticles were synthesised with Cassia fistula leaves. The difference between the wavelength peaks might be due to the difference in precursor salt and the type of leaf extract ( $P$. biglobossa) used for the preparation of $\mathrm{TiO}_{2}$ nanoparticles.

\section{FTIR analysis of $A A C$ and $\mathrm{TiO}_{2}-\mathrm{AAC}$}

The Fourier Transform Infrared spectroscopic analysis of the $\mathrm{AAC}$ and $\mathrm{TiO}_{2}$-AAC are presented in Fig. $2 \mathrm{a}$ and b. Several medium or low intense absorption bands can be noticed on the spectral of the AAC at $3857.76 \mathrm{~cm}^{-1}$ and $3734.31 \mathrm{~cm}^{-1}$. The absorption bands were assigned to the $\mathrm{O}-\mathrm{H}$ group stretch (Fig. 2a). The absorption bands at $3618.58 \mathrm{~cm}^{-1}$ represent $\mathrm{OH}$ bridging hydroxyls in the kaolin cages, bonded as $\mathrm{Al}-\mathrm{OH}-\mathrm{Si}$ similar to those observed in zeolite cages (Guillaume et al. 2018). The peaks between $3417.98 \mathrm{~cm}^{-1}$ and $3217.37 \mathrm{~cm}^{-1}$ suggest the $\mathrm{O}-\mathrm{H}-\mathrm{O}$ stretch of water molecules (Krishnan and Mahalingam 2017). The peak at $2337.80 \mathrm{~cm}^{-1}$ may be attributed to adsorbed $\mathrm{CO}_{2}$ while the peak $1681 \mathrm{~cm}^{-1}$ is related to-OH bend in water molecules found in typical kaolin clays (Kenne-Diffo et al. 2015). Similar peaks were also on the $\mathrm{TiO}_{2}-\mathrm{AAC}$, however with a slight shift and reduced intensity especially for the bonded hydroxyl group on $\mathrm{TiO}_{2}-\mathrm{AAC}$. The reduction in the intensity may be ascribed to the incorporation of $\mathrm{Ti}$ onto the kaolinite clay lattice. Also, the additional peaks at $914.87 \mathrm{~cm}^{-1}$, $869.92 \mathrm{~cm}^{-1}$, and $438 \mathrm{~cm}^{-1}$ were ascribed to the formation of Ti-O-Ti bonded, evidence of titanium (IV) oxide doping on the lattice layer of AAC, and by extension indicative of $\mathrm{TiO}_{2}$ pillared within the clay matrix (Guillaume et al., 2018).
Fig. 1 UV-visible spectroscopy of synthesised $\mathrm{TiO}_{2}$ using extract of Parkia biglobossa leaves
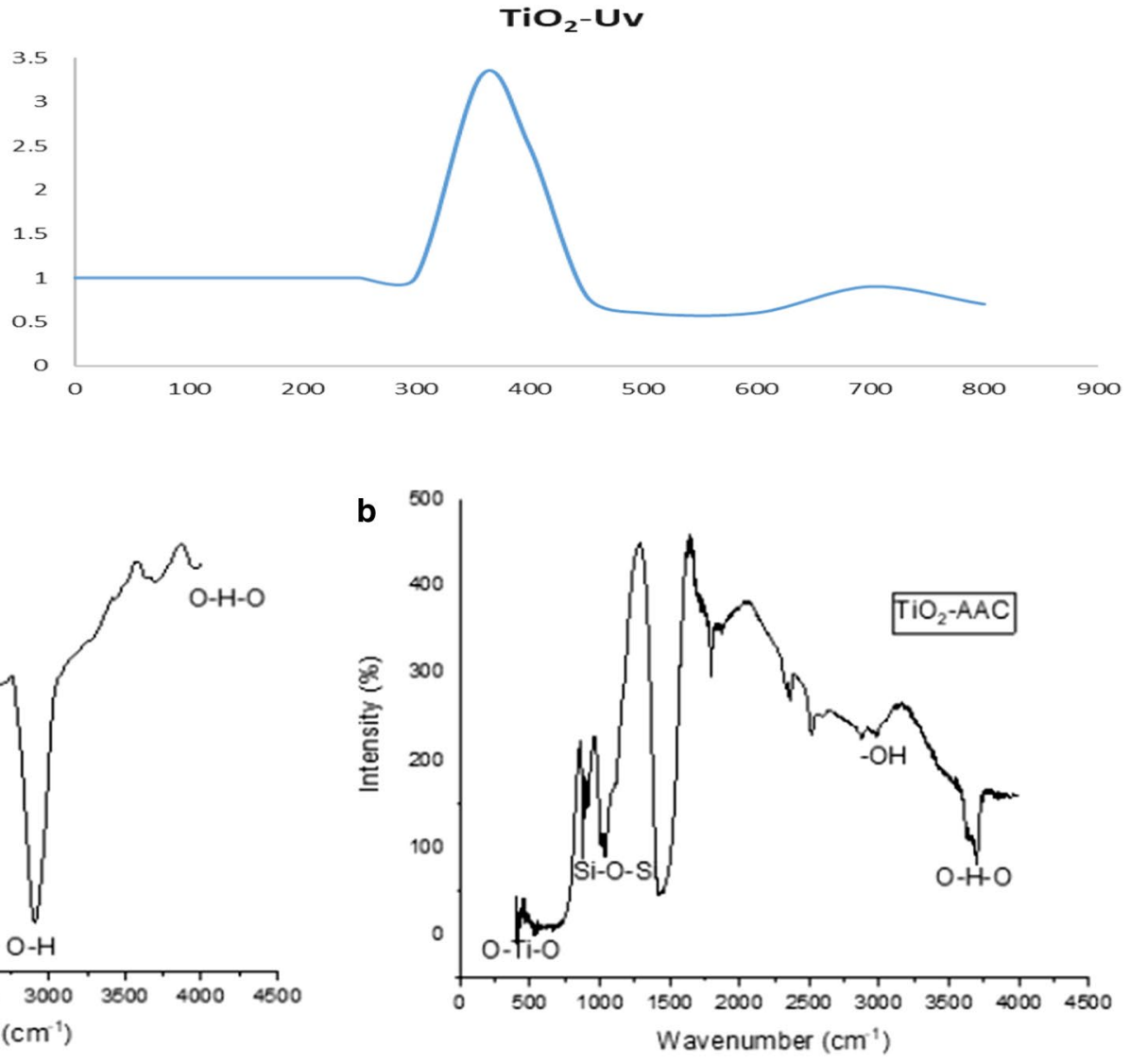

Fig. 2 FTIR spectral of $\mathbf{a} \mathrm{AAC}$ and $\mathbf{b} \mathrm{TiO}_{2}-\mathrm{AAC}$

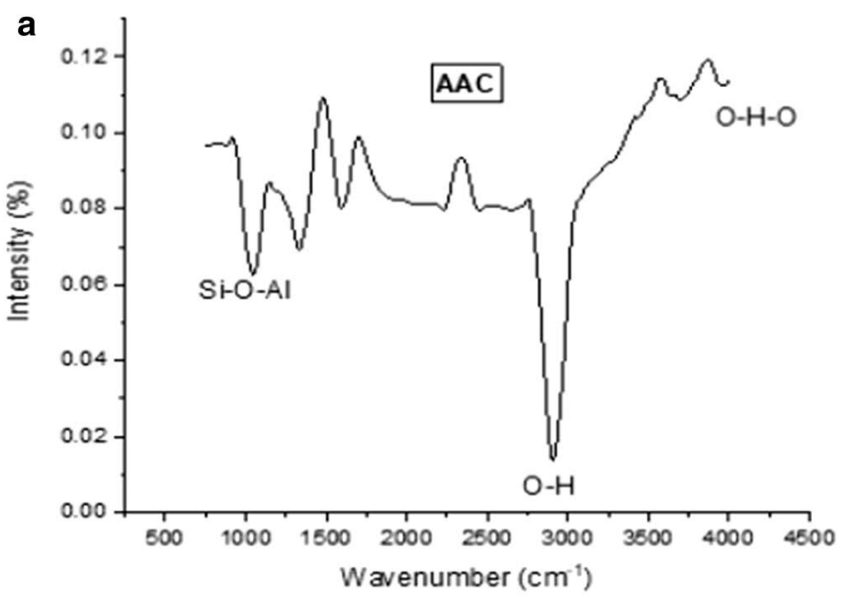




\section{XRD result}

X-ray diffraction (XRD) analysis was employed to show the crystallographic and mineralogical representation of the prepared samples. Figure $3 \mathrm{a}-\mathrm{c}$ represents the XRD pattern of the acid-activated clay (AAC), $\mathrm{TiO}_{2}$ and $\mathrm{TiO}_{2}$ modified acid-activated kaolinite clay $\left(\mathrm{TiO}_{2}\right.$-AAC). As shown in Fig. 3a different diffraction peaks were observed at 2 theta value of $12.36^{\circ}, 19.92^{\circ}, 24.80^{\circ}, 26.39^{\circ} 35.91^{\circ}$, $37.71^{\circ}, 38.4^{\circ}$ and $62.34^{\circ}$ with miller indices; (001), (020), (002), (003), (-131), (003), (-113) and (060), respectively. This corresponds to the presence of kaolinites type of clay. Other diffraction peaks on the AAC spectral at $2 \theta$ values of $20.93^{\circ}(100), 26.59^{\circ}(101), 36.48^{\circ}(110), 50.00^{\circ}(112)$ and 68.57 (134) (JCPDS card no-083-0539), indicating the presence of quartz in the acid-activated kaolinite clay with average crystallite size of $8.10 \mathrm{~nm}$. On the other hand, the XRD pattern of $\mathrm{TiO}_{2}$ revealed spectral the presence of strong, sharp and moderately intense diffraction peaks at $2 \theta$ values of $27.45^{\circ}, 36.16^{\circ}, 39.20^{\circ}, 44.05^{\circ}, 54.32,56.64^{\circ}$ and $69.79^{\circ}$. These peaks allied well to the crystal planes of (110), (111), (200), (210), (211), (220) and (112) with
(JCPDS number 00-021-1276) for a typical rutile phase of $\mathrm{TiO}_{2}$ with calculated crystallite size of $9.48 \mathrm{~nm}$. The crystallite size of $\mathrm{TiO}_{2}$ obtained in this study, is smaller and preferred than the earlier reports by Patidar and Jain (2017) who obtained $12.22 \mathrm{~nm}$ crystallite size for anatase titanium-dioxide prepared using Moringa oleifera leaves extract as a reducing agent. Zahir et al. (2015) obtained a $12.82 \mathrm{~nm}$ crystallite size anatase phase of $\mathrm{TiO}_{2}$ using Euphorbia prostrata, Landage et al. (2020) also obtained a $20 \mathrm{~nm}$-sized anatase-phase $\mathrm{TiO}_{2}$ using Staphylococcus aureus. Subhapriya and Gomathipriya (2018) obtained a 30 and $25 \mathrm{~nm}$ crystallite size $\mathrm{TiO}_{2}$ using Trigonella foenum with anatase cum rutile phase titanium synthesised while $92 \mathrm{~nm}$ crystallite sized anatase $\mathrm{TiO}_{2}$ nanoparticles were obtained by Abu-Dalo et al. (2019) using pristine pomegranate peel extract. Most of the synthesised $\mathrm{TiO}_{2}$ reported are anatase or mixed phases but not pure rutilephased $\mathrm{TiO}_{2}$, the difference in phase and size of $\mathrm{TiO}_{2}$ nanoparticles obtained were attributed to the nature of plant extracts and calcination temperature used during the synthesis. XRD spectra of $\mathrm{TiO}_{2}$-AAC revealed the existence of sharp and intense diffraction peaks of at 2

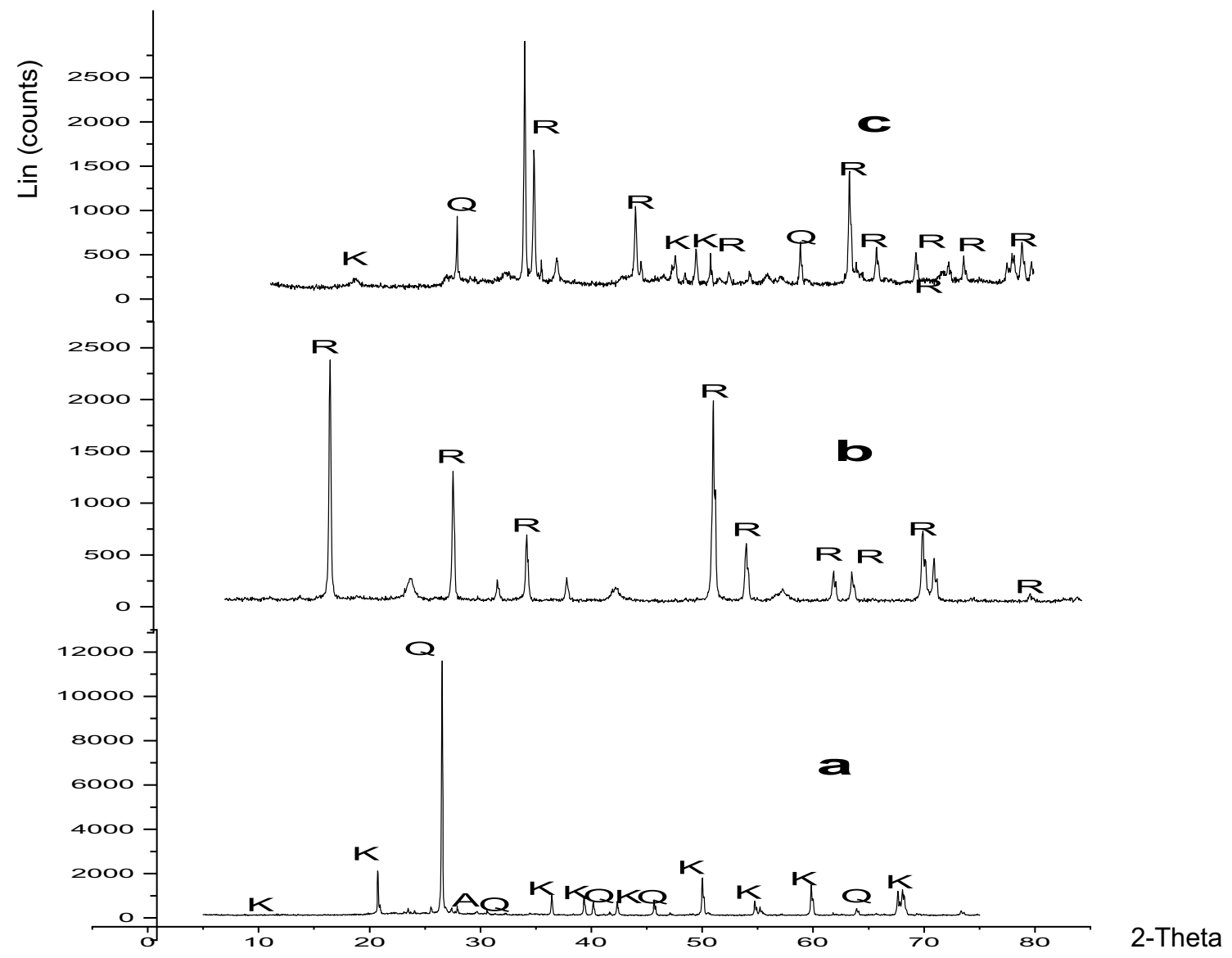

Fig. 3 XRD patterns of synthesised $\mathbf{a} \mathrm{AAC}, \mathbf{b} \mathrm{TiO}_{2}$ and $\mathbf{c} \mathrm{TiO}_{2}-\mathrm{AAC}$ 
theta value with corresponding miller indices of $12.43^{\circ}$

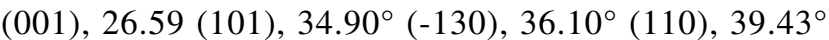
(012) and $40.42^{\circ}(111) 27.52^{\circ}(110), 41.22^{\circ}(111), 44.05^{\circ}$ (210), $54.32^{\circ}(211), 56.70^{\circ}(220)$. The characteristic peak of acid activated clay signified at $26.59^{\circ}$ (101) was overlap (110) plane of $\mathrm{TiO}_{2}$. A similar observation was noticed with for peak at $54.71^{\circ}(202)$, with overlapping effect on (211) plane of rutile $\mathrm{TiO}_{2}$. The overlapping phenomenon is evidence of the doping effect of kaolinite clay on $\mathrm{TiO}_{2}$ structure. The intensity of other diffraction peaks at $41.22^{\circ}$ (111), $44.05^{\circ}(210), 54.32^{\circ}(211), 56.70^{\circ}(220), 62.90^{\circ}$ $(002), 64.03^{\circ}(310)$, and $69.28^{\circ}(301)$ reduced due to the incorporation of kaolinite clay on $\mathrm{TiO} 2$ matrix. The reduction of crystallite size $\mathrm{TiO}_{2}$-AAC $(6.11 \mathrm{~nm})$ compared to $\mathrm{TiO}_{2}$ alone is evidence of improved dispersion of the $\mathrm{TiO}_{2}$ on the AAC framework.
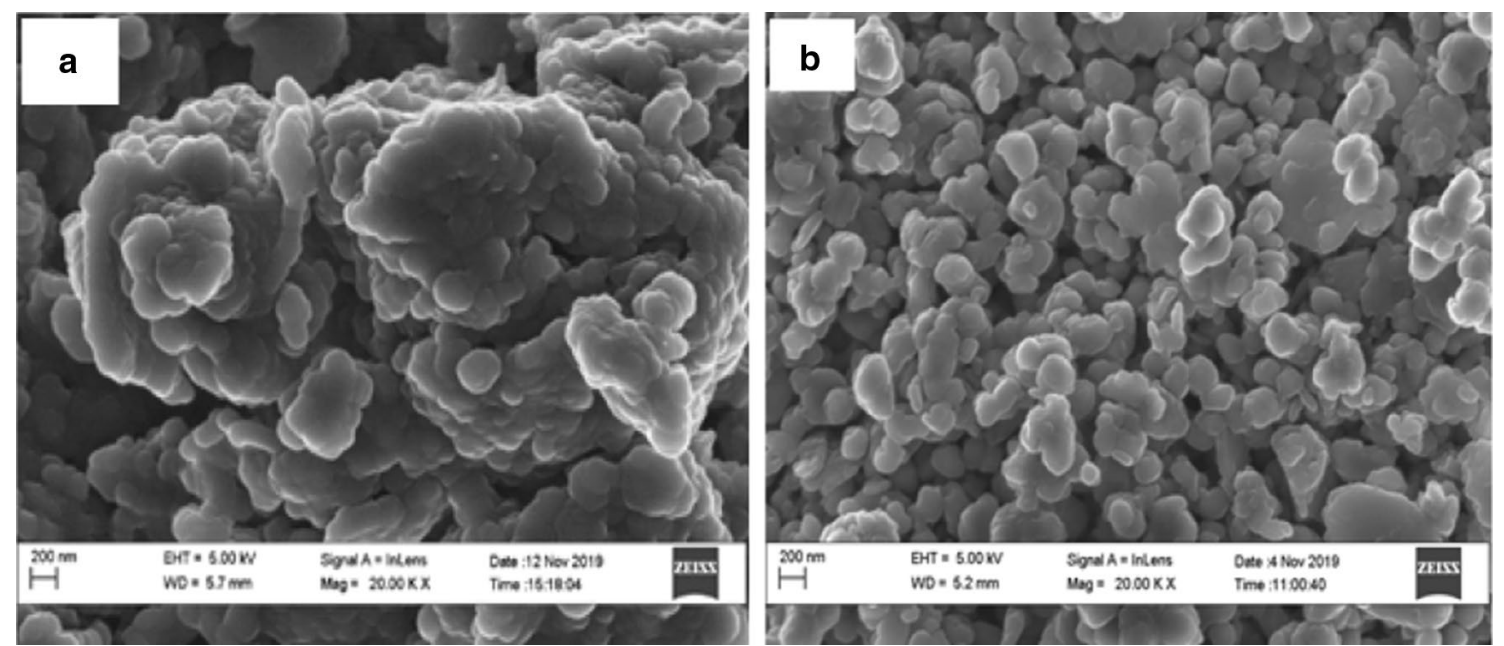

Fig. 4 HRSEM of a AAC b $\mathrm{TiO}_{2}-\mathrm{AAC}$
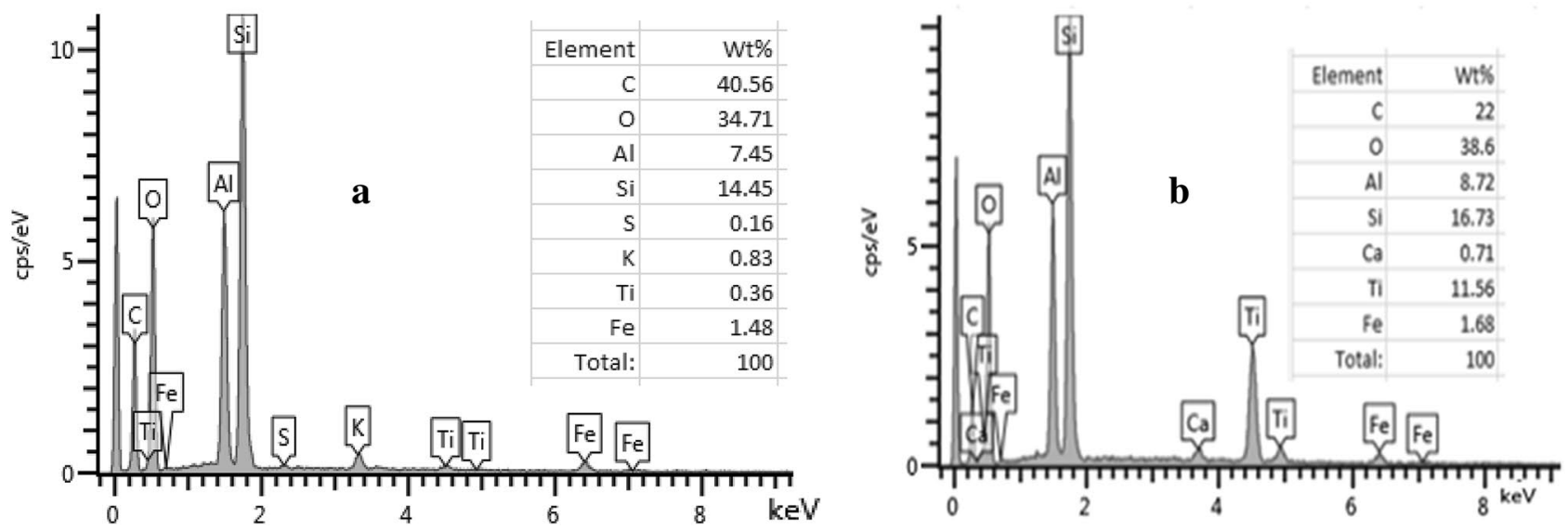

Fig. 5 EDS spectrum of $\mathbf{a} \mathrm{AAC}_{\mathbf{b}} \mathrm{TiO}_{2}-\mathrm{AAC}$

\section{HRSEM/EDS of the nanoparticles and composite}

The HRSEM of acid-activated kaolinite clay (AAC) and titanium (IV) oxide-activated clay $\left(\mathrm{AAC}-\mathrm{TiO}_{2}\right)$ are presented in Fig. $4 \mathrm{a}$, and $\mathrm{b}$. Figure a shows a well ordered, well-defined arrangement of kaolinite plates with induced porosity and smooth surfaces, due to acid treatment. Figure $4 \mathrm{~b}$ shows the arrangement of well ordered, well-defined intercalated, grain-like porous surface. The immobilization of the $\mathrm{TiO}_{2}$ onto acid-treated kaolinite clay showed a well dispersed and homogeneous distribution of spherical particles, and evidence the titanium (IV) oxide doped on the acid-activated clay surface.

The EDS result in (Fig. 5a and b) reveals the characteristic lines of carbon, oxygen, aluminium and silicon as the major elements in the acid-activated kaolinite clay and the 
$\mathrm{TiO}_{2}$ doped activated kaolinite clay. Calcium, titanium, sulphur and iron were also detected on the acid-activated clay. The sulphur was probably from the residual tetraoxosulphate (IV) acid used for acid activation. The percentages of the identified elements increased in Fig. 5b, due to the interaction of $\mathrm{TiO}_{2}$ with the acid-activated clay. The reduction in oxygen wt. $\%$ in the $\mathrm{TiO}_{2}-\mathrm{AAC}$ as compared with that in $\mathrm{TiO}_{2}$ is attributed to bonding with the $\mathrm{Si}$ and $\mathrm{Al}$ in the acid activation clay.

\section{BET analysis of $\mathrm{AAC}, \mathrm{TiO}_{2}$ and $\mathrm{TiO}_{2}-\mathrm{AAC}$ composite}

The $\mathrm{N}_{2}$ adsorption-desorption curve for the three materials (AAC, $\mathrm{TiO}_{2}$ and $\mathrm{TiO}_{2}$-AAC) is shown in Fig. 6, while the parameters (surface area, pore diameter and pore volume) are presented in Table 2 . The $\mathrm{TiO}_{2}$ has $10.23 \mathrm{~m}^{2} / \mathrm{g}$ of surface area while the AAC has $14.15 \mathrm{~m}^{2} / \mathrm{g}$ which shows that the latter has a larger surface area than the former. This claim is similar to the findings of Akinnawo (2019); Krishnan and Mahalingam (2017) where they also reported low surface area for $\mathrm{TiO}_{2}$. However, the higher surface area of the $\mathrm{TiO}_{2}-\mathrm{AAC}\left(32.98 \mathrm{~m}^{2} / \mathrm{g}\right)$ was due to modification by the rutile- $\mathrm{TiO}_{2}$ which agrees with the literature (Bok-Badura et al. 2018; Krishnan and Mahalingam 2017). The specific surface area and pore volume of $\mathrm{TiO}_{2}-\mathrm{AAC}$ were significantly increased to $32.98 \mathrm{~m}^{2} / \mathrm{g}$ due to the dispersed stacking of $\mathrm{TiO}_{2}$ on the surface of the acid-activated clay.

However, the pore diameter of the prepared $\mathrm{TiO}_{2}-\mathrm{AAC}$ decreased after the modification by $\mathrm{TiO}_{2}$ due to the in-situ
Table 2 BET surface area, pore diameter, pore volume of AAC, $\mathrm{TiO}_{2}$ and $\mathrm{TiO}_{2}-\mathrm{AAC}$

\begin{tabular}{llll}
\hline Sample & Surface area $\mathrm{m}^{2} / \mathrm{g}$ & $\begin{array}{l}\text { Pore diameter } \\
(\mathrm{nm})\end{array}$ & $\begin{array}{l}\text { Pore } \\
\text { volume } \\
(\mathrm{cc} / \mathrm{g})\end{array}$ \\
\hline $\mathrm{AAC}$ & 14.15 & 17.66 & 0.069 \\
$\mathrm{TiO}_{2}$ & 10.23 & 4.09 & 0.093 \\
$\mathrm{TiO}_{2}$-AAC & 32.98 & 4.86 & 0.150 \\
\hline
\end{tabular}

deposition of the $\mathrm{TiO}_{2}$ on AAC, which blocked a large number of accumulated pores on $\mathrm{TiO}_{2}-\mathrm{AAC}$. On the other hand, the $\mathrm{TiO}_{2}-\mathrm{AAC}$ composite has a large specific surface area and pore volume, which is conducive for the removal and capturing of pollutants molecules from the aqueous matrix by the composite materials. According to the IUPAC classification, the three samples demonstrated a typical type IV adsorption isotherm of a typical mesoporous structure, similar to the one obtained by Malima et al. (2018). Besides, pure $\mathrm{TiO}_{2}$ has a typical $\mathrm{H} 1$ hysteresis loop, which indicated the stacked mesoporous structure derived from the accumulated spherical particles. Other samples display $\mathrm{H} 3$ hysteresis loops, which indicates that they have irregular mesopores and macropores due to the irregular shape of particles and the composition of different components. The construction of a combined structure improves the particular surface area and pore volume of the $\mathrm{TiO}_{2}-\mathrm{AAC}$. The extensively constructed mesopores give the $\mathrm{TiO}_{2}-\mathrm{AAC}$ significant adsorption capacity, which may enhance the adsorption ability of
Fig. 6 BET adsorption-desorption isotherms plots of a AAC, b $\mathrm{TiO}_{2}$ and $\mathbf{c} \mathrm{TiO}_{2}-\mathrm{AAC}$

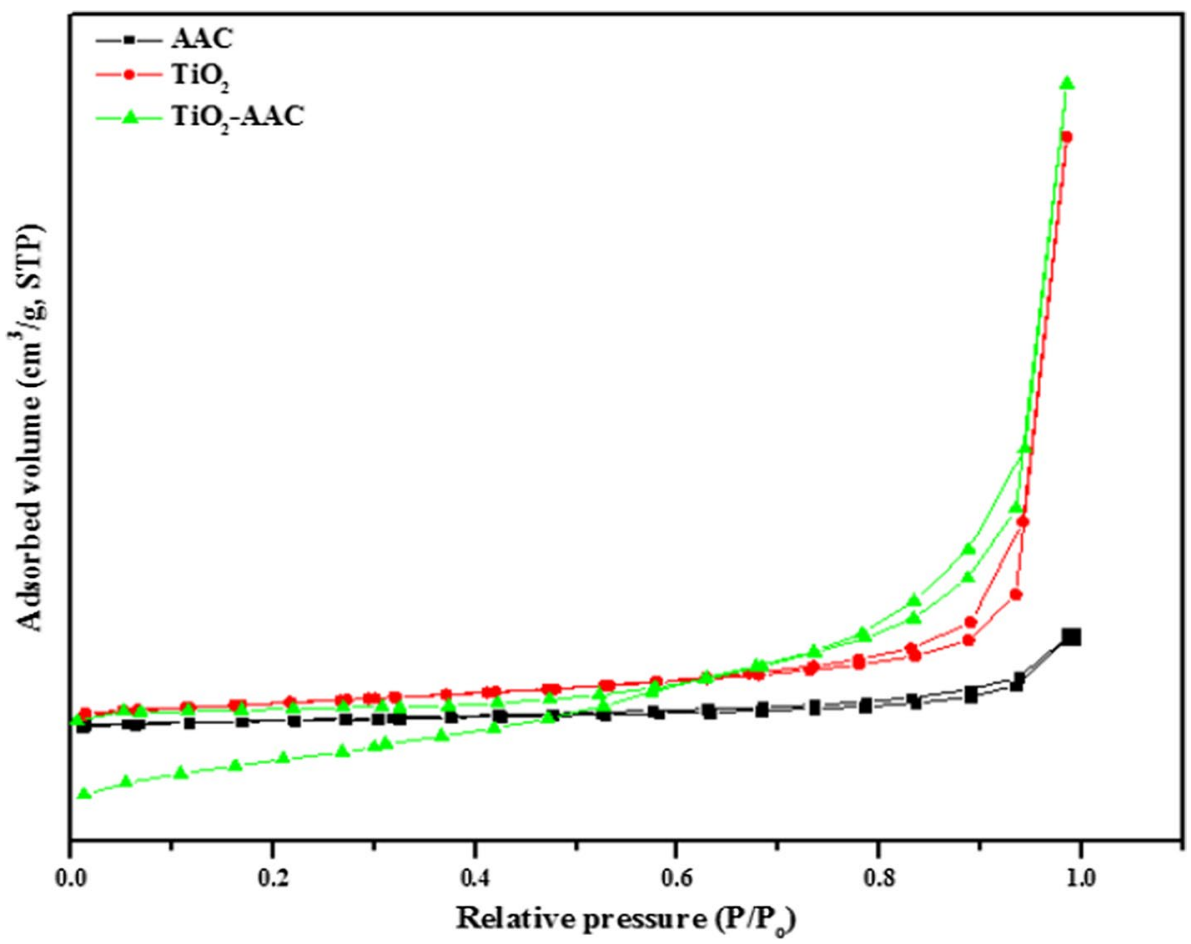


the $\mathrm{TiO}_{2}-\mathrm{AAC}$ materials than the other two materials (Xiang et al. 2019).

\section{XPS analysis of $A A C$ and $\mathrm{TiO}_{2}-\mathrm{AAC}$}

The XPS analysis was conducted to determine the surface oxidation state and orbital of each element present in the samples. Figures 7ai and ii shows the general survey spectrum of the rutile titanium dioxide nanoparticles, activated clay (AAC) and titanium (IV) oxide-activated clay The XPS of the activated clay sample (Fig. 7ai), reveals the presence of $\mathrm{Si}(2 p)$ at binding energies of 103.14(eV), C (1 s) at $284.8 \mathrm{eV}$. A narrow but sharp peak of oxygen $(1 \mathrm{~s})$ occurs at the binding energy of $529.7 \mathrm{eV}$. The Si Originated from the acid-activated clay because clays are generally made up of aluminium and silicon (alumino-silicates) elements but in varied ratios (Pimneva 2019). Figure 7 aii $\left(\mathrm{TiO}_{2}-\mathrm{AAC}\right.$ XPS spectral) revealed the presence of $\mathrm{Ti}\left(2 p_{3 / 2}\right)$ orbital at a binding energy of $458.3 \mathrm{eV}$, while a sharp narrow peak of oxygen $(1 \mathrm{~s})$ was also found at the binding energy of $529.7 \mathrm{eV}$ and carbon ( $1 \mathrm{~s})$ at $284.8 \mathrm{eV}$. The narrow and sharp peak seen around binding energies of $458.34 \mathrm{eV}$ shows the presence of $\mathrm{Ti} 2 \mathrm{p}_{3 / 2}$. This confirms the formation of pure rutile $\mathrm{TiO}_{2}$. The binding energies obtained for titanium and oxygen matched well with the literature (Krishnan and Mahalingam 2017).

Figure $7 \mathrm{~b}$ displays the XPS of Ti $2 p$ deconvoluted spectra in $\mathrm{TiO}_{2}$ and $\mathrm{TiO}_{2}-\mathrm{AAC}$. The figure reveals the presence of two sharp peaks on each deconvoluted spectra at
Fig. 7 XPS spectral of a i AAC, ii $\mathrm{TiO}_{2}-\mathrm{AAC}$ and $\mathbf{b}$ deconvoluted spectral of $\mathrm{Ti}$ in $\mathrm{TiO}_{2}$ and $\mathrm{TiO}_{2}-\mathrm{AAC}$
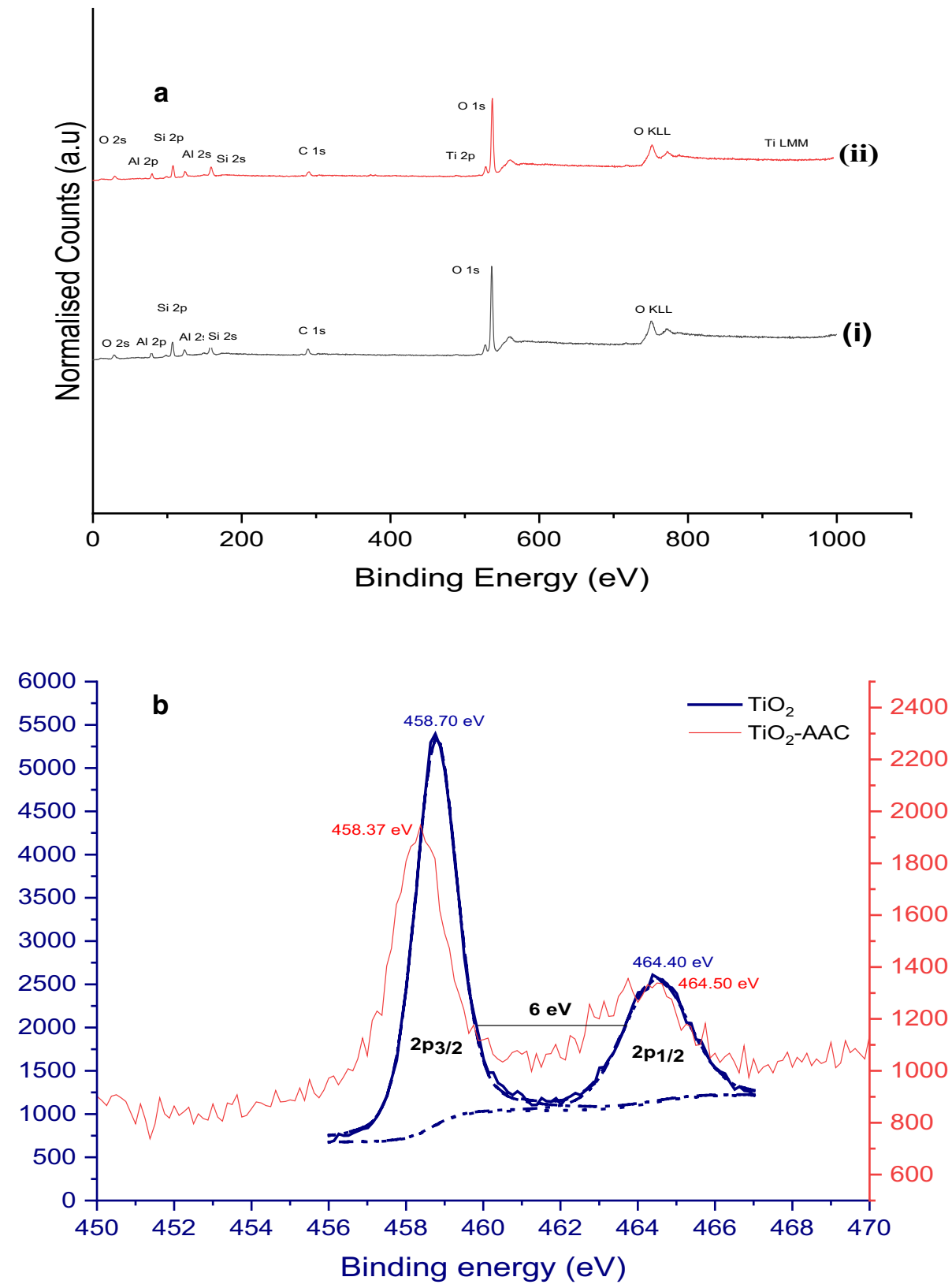
binding energies of $458.70 \mathrm{eV}$ and $464.40 \mathrm{eV}$ in $\mathrm{TiO}_{2}$, with $458.37 \mathrm{eV}$ and $464.50 \mathrm{eV}$ in $\mathrm{TiO}_{2}-\mathrm{AAC}$ respectively, for the XPS deconvoluted spectrum in the Ti $2 p$ region. These peaks are assigned to $2 p_{3 / 2}$ and $2 p_{1 / 2}$, both spectral shows the difference of 5.80 and $6.03 \mathrm{eV}(\sim 6 \mathrm{eV})$, an indication that the $\mathrm{TiO}_{2}$ exists in the oxidation state of +4 in the spectra of both $\mathrm{TiO}_{2}$ nanoparticles and $\mathrm{TiO}_{2}$-AAC despite the modification. This corroborates the reported values in the literature (Li et al. 2015).

\section{Heavy metals characterisation of the mining wastewater.}

The mining site wastewater was characterised for the presence of heavy metals concentrations present therein. The table, therefore, presents the heavy metals, concentrations in the mining wastewater and their standard organisation permissible limit (Table 3).

From the table, it was observed that the mining wastewater has a $\mathrm{pH}$ higher than the permissible in drinking water by both WHO and NIS standards. The pH is a serious but simple parameter that determines most chemical reactions in aquatic mediums. Very high or very low $\mathrm{pH}$ value can be harmful to aquatic life. The $\mathrm{pH}$ of the mining waste water is acidic due to the acid mine drainage generation process. This acidic water can cause different skin diseases and the death of aquatic organisms due to sensitivity (Masindi and Muedi 2018). Moreover, the presence of heavy metals such as $\mathrm{Fe}, \mathrm{Cu}, \mathrm{Mn}, \mathrm{Ni}, \mathrm{Cd}, \mathrm{Pb}$ and $\mathrm{Cr}$ in wastewater have been reported to cause; mental retardation $(\mathrm{Pb})$, skin rashes, respiratory problems $(\mathrm{Cr})$, critical renal failure (Mn), debilitated immune systems, liver and kidney damage, cancer, chest pain, rapid respiration (Ni) (BalaliMood et al. 2021; Lakherwal 2014). It can be seen from the Table that iron has a concentration of $20.013 \mathrm{mg} / \mathrm{L}$, which is greater than the WHO standard of $3 \mathrm{mg} / \mathrm{L}$ but lesser than $64.96 \mathrm{mg} / \mathrm{L}$ obtained by Kamal and Gooyong (2019) from an AMD, nickel was $0.326 \mathrm{mg} / \mathrm{L}$ below WHO permissible

Table 3 Heavy metals parameters in the mining wastewater

\begin{tabular}{llll}
\hline Parameter & Initial values & WHO/EPA (2017) & NIS (2015) \\
\hline $\mathrm{pH}$ & 5.92 & $6.50-8.50$ & $6.50-8.50$ \\
$\mathrm{Fe}(\mathrm{mg} / \mathrm{L})$ & 20.02 & $1.00-3.00$ & 0.3 \\
$\mathrm{Cu}(\mathrm{mg} / \mathrm{L})$ & 0.31 & 0.05 & 1 \\
$\mathrm{Mn}(\mathrm{mg} / \mathrm{L})$ & 4.29 & 0.05 & 0.2 \\
$\mathrm{Cd}(\mathrm{mg} / \mathrm{L})$ & $\mathrm{ND}$ & 0.005 & 0.003 \\
$\mathrm{Ni}(\mathrm{mg} / \mathrm{L})$ & 0.33 & 3.00 & 0.02 \\
$\mathrm{~Pb}(\mathrm{mg} / \mathrm{L})$ & 0.98 & 0.015 & 0.01 \\
$\mathrm{Cr}(\mathrm{mg} / \mathrm{L})$ & 0.10 & 0.10 & 0.05 \\
$\mathrm{Colour}$ & Dark & Clear & Clear \\
Odour & Offensive & Odourless & Odourless \\
\hline
\end{tabular}

limit concentrations of 3.0, therefore acceptable. Low $\mathrm{Ni}$ concentrations of 1 and $2.97 \mathrm{mg} / \mathrm{L}$ was also obtained by Esmaeili et al. (2019) and Masindi and Muedi (2018). Previous studies documented varied concentrations of pollutants in mining wastewater (Kamal and Gooyong 2019; Madzivire et al. 2011; Masindi and Muedi 2018). Xie et al. (2018) reported $0.008-3.355 \mathrm{mg} / \mathrm{L}$ of $\mathrm{Cu}, 0.058-0.349 \mathrm{mg} / \mathrm{L} \mathrm{of} \mathrm{Pb}$, $0.035-0.476 \mathrm{mg} / \mathrm{L}$ of $\mathrm{Ni}$, and $0.006-0.022 \mathrm{mg} / \mathrm{L}$ of $\mathrm{Cr}$ all lower than the values obtained in this study (Chanchaga mining wastewater). Variations observed in heavy metal ion concentrations at various sites is due to; the $\mathrm{pH}$ variation of the concerned AMD. This is because concentrations decrease when $\mathrm{pH}$ increases (Masindi and Muedi 2018). Additionally, the presence of dark colour (coloured water) and foul odour as presented on the Table in the mining wastewater is a characteristic property of AMD (Kefeni et al. 2017; Seo et al. 2016). This earlier listed contaminants at their concentrations make life difficult for aquatic species due to low oxygen content. The earlier mentioned contaminants level revealed that the mining wastewater cannot be directly released into the environment without proper treatment and therefore, the need for adsorptive removal of the heavy metals using AAC and $\mathrm{TiO}_{2}-\mathrm{AAC}$.

\section{Metal ion adsorption experimental results}

\section{Effect of contact time}

Figure $8 \mathrm{a}$ and $\mathrm{b}$ depicts the effect of variation of contact time on the uptake of $\mathrm{Mn}$ (II), $\mathrm{Fe}$ (III), $\mathrm{Pb}$ (II) and $\mathrm{Cu}$ (II) from mining wastewater onto the $\mathrm{AAC}$ and $\mathrm{TiO}_{2}-\mathrm{AAC}$. The quantity of each metal ion adsorbed was found to increase with increased time from 20 to $180 \mathrm{~min}$ for the two adsorbents. AAC steadily removed $57.00 \% \mathrm{Mn}$ (II), $40.76 \% \mathrm{Cu}$ (II), $58.92 \% \mathrm{Fe}$ (III), and $20.17 \% \mathrm{~Pb}$ (II) maximum at an equilibrium time of $140 \mathrm{~min}$. There was a drastic increase in the percentage removal by the $\mathrm{TiO}_{2}$-AAC at the first 60 min compared to $\mathrm{AAC}$ alone and continued gradually until $120 \mathrm{~min}$, with total removals of $80.23 \%$ Mn (II), $85.12 \% \mathrm{Fe}$ (III), $78.42 \% \mathrm{Cu}$ (II) and $20.42 \% \mathrm{~Pb}$ (II) (Fig. 8b). Rapid initial adsorption may be attributed to available surface adsorption sites on $\mathrm{AAC}$ and $\mathrm{TiO}_{2}-\mathrm{AAC}$. Adsorption equilibrium on the surface of $\mathrm{TiO}_{2}-\mathrm{AAC}$ was completely attained at $120 \mathrm{~min}$ for $\mathrm{Mn}$ (II), $\mathrm{Pb}$ (II) and $\mathrm{Cu}$ (II) ions, while $\mathrm{Fe}$ (III) ions had reached equilibrium with total removal at the first 80 min of the adsorption experiment. The difference in equilibrium time of adsorption of each ion may be attributed to ionic radii, selectivity of the heavy metal by the adsorbents, the surface charge of adsorbent and difference in hydration energy; $\mathrm{Cu}(-2010 \mathrm{~kJ} /$ $\mathrm{mol}), \mathrm{Mn}(-1760 \mathrm{~kJ} / \mathrm{mol})$ and $\mathrm{Pb}$ ions $(-1481 \mathrm{~kJ} / \mathrm{mol})$. The higher the hydration energy, the faster the ease of adsorption (Zendelska et al. 2018). The order of removal 
Fig. 8 Effect of time on the adsorption of metal ions by a AAC b $\mathrm{TiO}_{2}-\mathrm{AAC}$ using $0.5 \mathrm{~g}$ adsorbent dosage, $30^{\circ} \mathrm{C}$ temperature and $20-180 \mathrm{~min}$ contact time
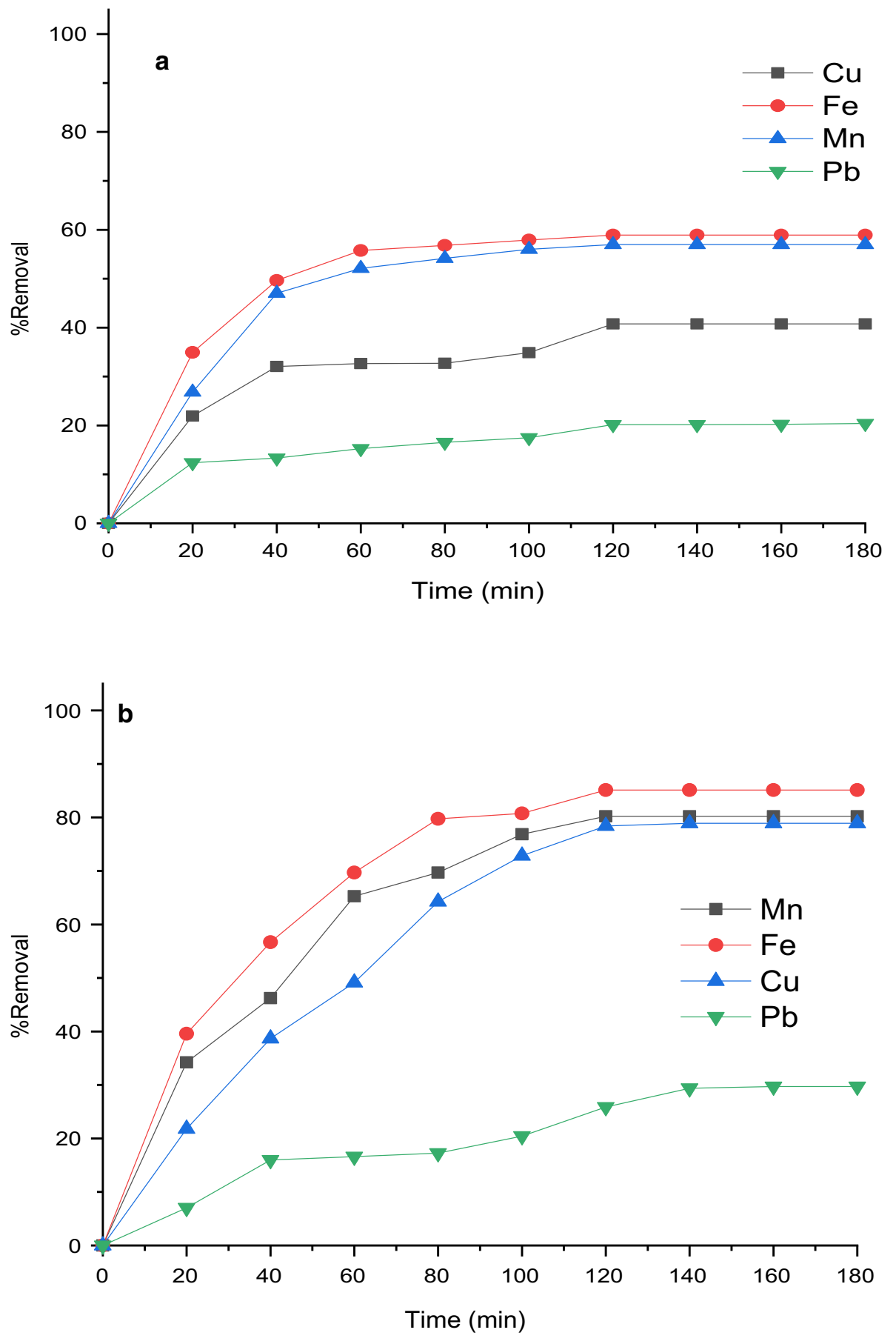

being; $\mathrm{Fe}$ (III) $>\mathrm{Mn}$ (II) $>\mathrm{Cu}$ (II) $>\mathrm{Pb}$ (II) As time progresses from 80 to $120 \mathrm{~min}$, the adsorptive surfaces on the $\mathrm{TiO}_{2}-\mathrm{AAC}$ were saturated with metal ions resulting in the repulsion between the adsorbed ions on the adsorbent material and those in the bulk solution signifying attainment of equilibrium for the four ions. The enhanced adsorptive performance of $\mathrm{TiO}_{2}-\mathrm{AAC}$ more than AAC alone can be linked to higher surface area and more functional groups of the former adsorbent than the latter one.

\section{Effect of adsorbent dosage}

The effect of adsorbent dosage on $\mathrm{Mn}$ (II), $\mathrm{Fe}$ (III), $\mathrm{Pb}$ (II) and $\mathrm{Cu}$ (II) ions adsorption from mining wastewater onto $\mathrm{AAC}$ and $\mathrm{TiO}_{2}-\mathrm{AAC}$ was investigated and the results are presented in Fig. 9a and b. As shown in Fig. 10a, it was noticed that the uptake level of $\mathrm{Mn}$ (II), $\mathrm{Fe}$ (III) and $\mathrm{Pb}$ (II) ions increase as the dosage increased from 0.1 to $0.4 \mathrm{~g}$, with $69.80 \%$ for $\mathrm{Mn}$ (II), $59.57 \%$ for $\mathrm{Fe}$ (III), $68.47 \%$ for $\mathrm{Pb}$ (II), 
Fig. 9 Effect of a AAC and b $\mathrm{TiO}_{2}-\mathrm{AAC}$ adsorbent dosage on the adsorption of metal ions using $0.1-1.0 \mathrm{~g}$ adsorbent dosage, $70{ }^{\circ} \mathrm{C}$ temperature and 120 min contact time
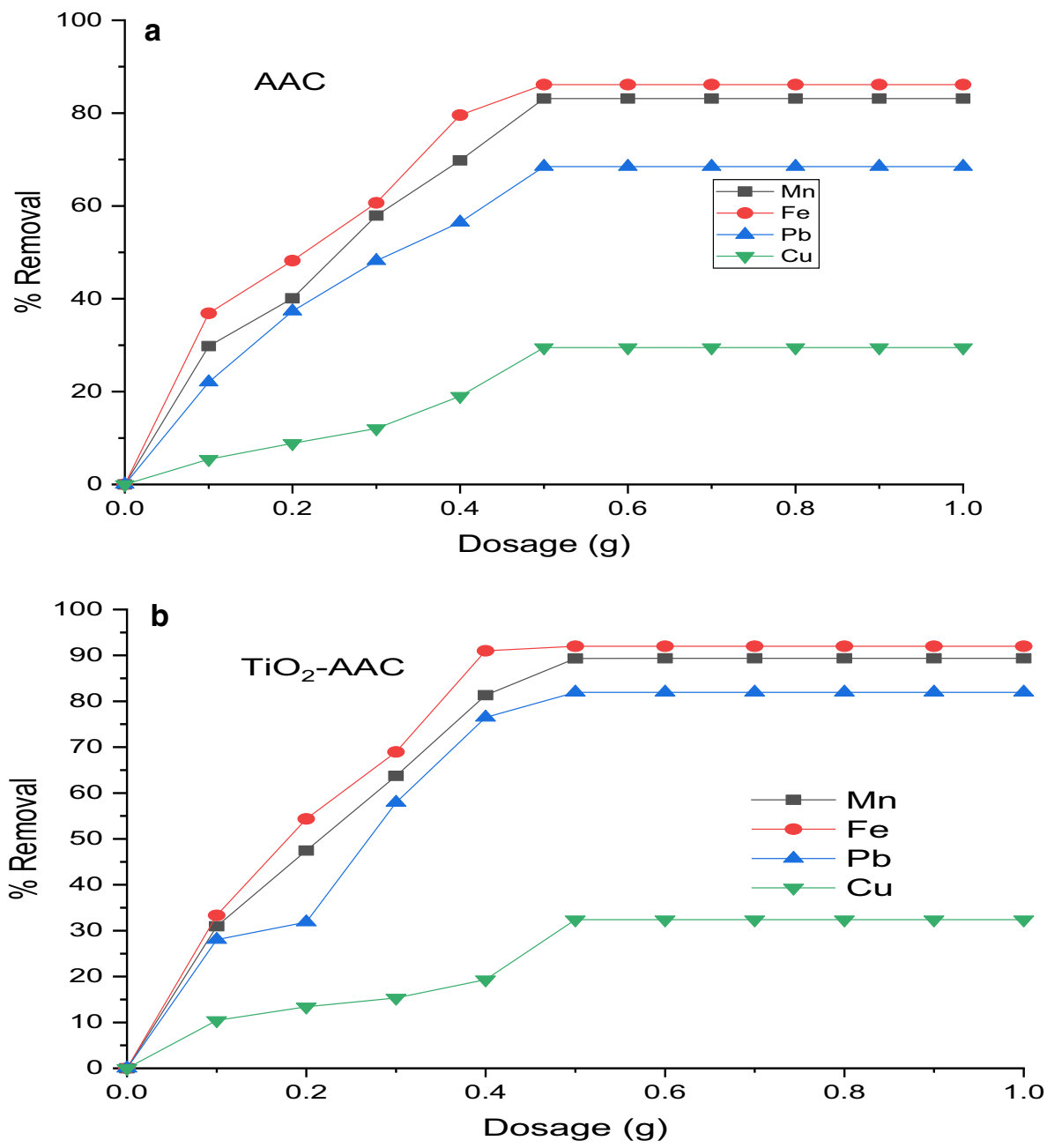

while $19.00 \%$ of $\mathrm{Cu}$ (II) was removed. When $0.5 \mathrm{~g}$ dosage was used, $83.12 \%, 86.13 \%$ and $68.47 \%$ of $\mathrm{Mn}$ (II), Fe (III) and $\mathrm{Cu}$ (II) ions were removed respectively, (see Fig. 9a), however, the percentage removal of $\mathrm{Pb}$ (II) ions was only $29.48 \%$ using $0.5 \mathrm{~g}$ adsorbent dosage. No substantial change is observed in the percentage removal of the four ions when the dosage was increased from 0.6 to $1.0 \mathrm{~g}$. This observation can be explained in terms of exposure to substantial number of accessible binding sites to the small adsorbate in the medium, which resulted to less per gram adsorption. This prevented the nanoadsorbent with dosage greater than $0.5 \mathrm{~g}$ to be shielded from further adsorbing heavy metal ions (Adebayo et al. 2020).

The removal efficiency of the four ions with AAC and $\mathrm{TiO}_{2}-\mathrm{AAC}$ increasing dosage of $0.1-1.0 \mathrm{~g}$ increase relatively. This is as result of an increase in the number of active sites available for the adsorption process (Abunah et al. 2019). However, there is no desirable change in the adsorptive capacity of $\mathrm{Pb}$ (II) ions even at maximum adsorbent dosage, as $\mathrm{Pb}$ (II) was the least adsorbed (29.48\%). Mn (II), Fe (III) and Cu (II) ions, \% removal onto AAC were 83.12, 86.13,68.47\%, respectively, while AAC-TiO 2 had percentage removal up to $89.34 \%, 91.97 \%$, $76.47 \%$ and $32.39 \%$ respectively for $\mathrm{Mn}$ (II), $\mathrm{Fe}$ (III), $\mathrm{Cu}$ (II) and $\mathrm{Pb}$ (II). It was observed that at every dosage of the adsorbent, $\mathrm{TiO}_{2}$-AAC sequestered more of the heavy metals ions than AAC due to its higher surface area and more functional groups than AAC alone. From the results, it was observed that there was strong selectivity among the metal ions by the active sites based on their ionic radius. It was found that the ions with smaller ionic radius diffused faster (onto the adsorbent surface) than the heavier ones. This is in the migration order of; Fe (III), $0.06 \mathrm{~nm}>\mathrm{Mn}$ (II) $0.072 \mathrm{~nm}>\mathrm{Cu}$ (II) $0.073 \mathrm{~nm}$ except for $\mathrm{Pb}$ (II) ions $0.119 \mathrm{~nm}$ which is heavy and has high ionic radii, thus retarding its diffusion capability onto the pores of the adsorbent. The result is similar to the report of Mobasherpour et al. (2012), who considered comparative adsorption of $\mathrm{Pb}$ (II), Cd (II) and $\mathrm{Ni}$ (II) from aqueous solution onto nano crystallite hydroxyapatite and found that ionic radii of the competing metal ions affect the rate of their adsorption from the aqueous solution. 
Fig. 10 Effect of temperature on the adsorption of metal ions onto $\mathbf{a} \mathrm{AAC}$ and $\mathbf{b} \mathrm{TiO}_{2}-\mathrm{AAC}$ using $0.5 \mathrm{~g}$ adsorbent dosage, 30-70 ${ }^{\circ} \mathrm{C}$ temperature and 120 min contact time
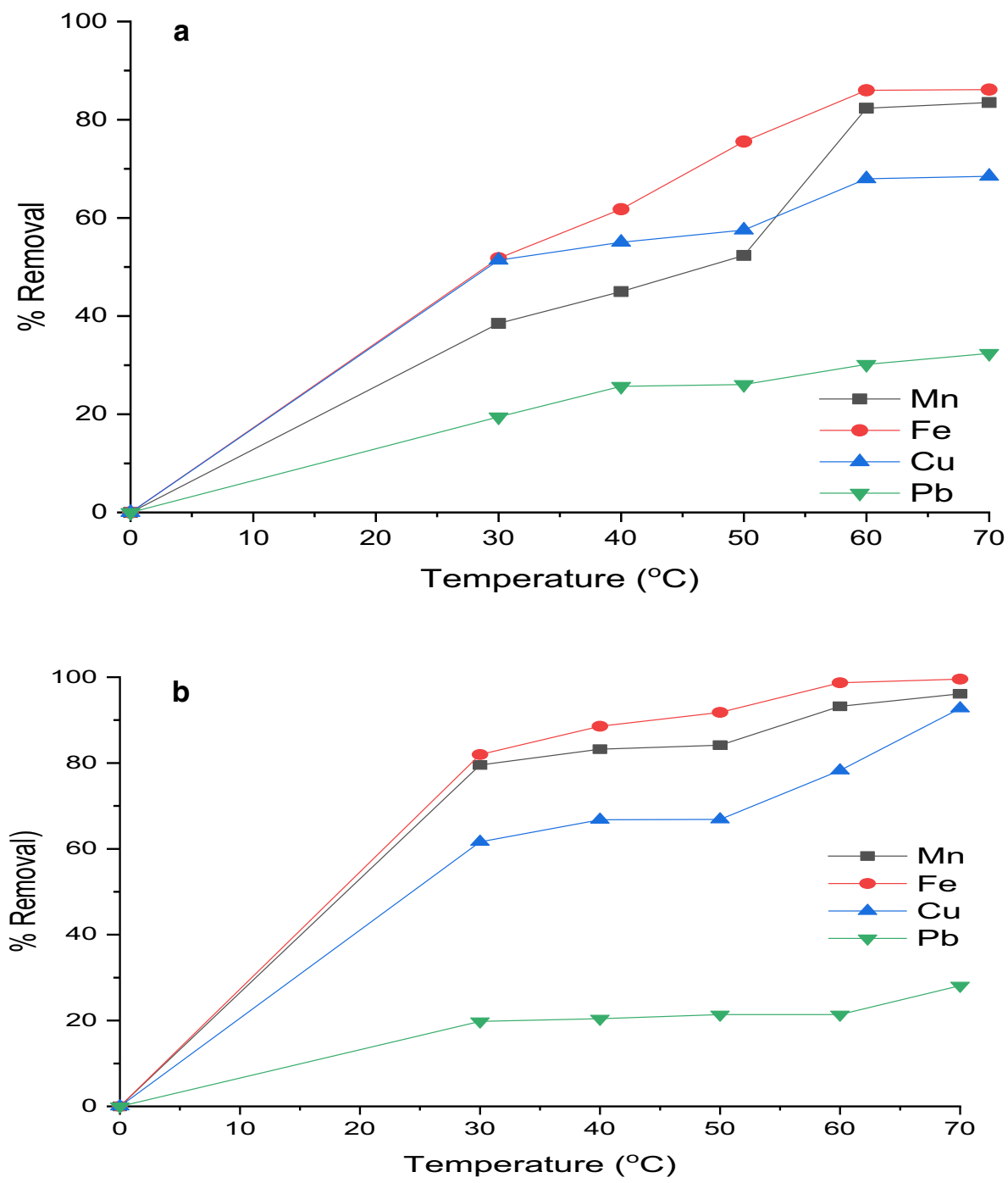

\section{Effect of temperature}

The percentage removal of $\mathrm{Mn}$ (II), $\mathrm{Fe}$ (III), $\mathrm{Pb}$ (II) and $\mathrm{Cu}$ (II) ions by the $\mathrm{AAC}$ and $\mathrm{AAC}-\mathrm{TiO}_{2}$ was studied as a function of temperature from $30,40,50,60$ and $70{ }^{\circ} \mathrm{C}$ and the result presented in Fig. 10a and b. The effect of temperature is an important parameter to be studied in adsorption processes because, the type of reaction and the reaction mechanism of the adsorption process can be evaluated (Alaya-Ibrahim et al. 2019). Adsorption can be physical or chemical depending on the type of attraction binding the adsorbate onto the adsorbent. From the figures, the percentage removal of $\mathrm{Mn}$ (II), $\mathrm{Fe}$ (III), $\mathrm{Pb}$ (II) and $\mathrm{Cu}$ (II) ions by the $\mathrm{AAC}$ and $\mathrm{TiO}_{2}-\mathrm{AAC}$ improved sharply, as the temperature increases from 30 to $50{ }^{\circ} \mathrm{C}$. As the temperature increases to 60 and $70{ }^{\circ} \mathrm{C}$, a comparable amount of metal ion was removed by the two nano adsorbents. For the AAC, the maximum removal efficiency of 83.45 ,
$86.13,68.47$ and $29.39 \%$ were obtained for $\mathrm{Mn}$ (II), $\mathrm{Fe}$ (III), $\mathrm{Cu}$ (II) and $\mathrm{Pb}$ (II) ions respectively at $70^{\circ} \mathrm{C}$. On the $\mathrm{TiO}_{2}-\mathrm{AAC}$, it was discovered that, the percentage removal of $\mathrm{Mn}$ (II), $\mathrm{Fe}$ (III), $\mathrm{Cu}$ (II) and $\mathrm{Pb}$ (II) ions also increased steadily with an increase in temperature from 30 to $70{ }^{\circ} \mathrm{C}$ with $89.36 \% \mathrm{Mn}$ (II), $91.99 \% \mathrm{Fe}$ (III), $81.94 \% \mathrm{Cu}$ (II) and $32.39 \% \mathrm{~Pb}$ (II) ion removal at maximum. The increase in efficiency of the nanocomposite material accompanied by increase in temperature from 30 to $70{ }^{\circ} \mathrm{C}$ may be due to the increased mobility (Alaya-Ibrahim et al. 2019) of the heavy metals towards the binding sites on $\mathrm{TiO}_{2}-\mathrm{AAC}$ than $\mathrm{AAC}$ as temperature increases. It was also noticed that the adsorbent performance under the influence of temperature was in the order of $\mathrm{TiO}_{2}-\mathrm{AAC}>\mathrm{AAC}$. Therefore, the adsorption taking place may be described as a chemisorption process (Alaya-Ibrahim et al. 2019; Bankole et al. 2019). 


\section{Adsorption Isotherms of the AAC and $\mathrm{TiO}_{2}-\mathrm{AAC}$}

The interaction of the raw mining wastewater containing $4.291 \mathrm{mg} / \mathrm{L} \mathrm{Mn}$ (II), $20.013 \mathrm{mg} / \mathrm{L}$ Fe (III), $0.975 \mathrm{mg} / \mathrm{L}$ $\mathrm{Cu}$ (II) and $0.313 \mathrm{mg} / \mathrm{L} \mathrm{Pb}$ (II) ions with the $\mathrm{AAC}$ and $\mathrm{TiO}_{2}-\mathrm{AAC}$ shows a reduction in the metal ion concentration at equilibrium to $0.155 \mathrm{mg} / \mathrm{L} \mathrm{Mn}(\mathrm{II}), 0.014 \mathrm{mg} / \mathrm{L} \mathrm{Fe}$ (III), $0.01 \mathrm{mg} / \mathrm{L} \mathrm{Cu}$ (II) and $0.128 \mathrm{mg} / \mathrm{L} \mathrm{Pb}$ (II) respectively. The values obtained using both adsorbents were lesser than their permissible standard concentration in drinking water as stated by EPA and WHO (WHO 2017). The equilibrium data were evaluated using Langmuir, Freundlich, Temkin and $D-R$ isotherm models. The interaction was carried out to correlate the equilibrium experimental data of $\mathrm{Mn}$ (II), $\mathrm{Fe}(\mathrm{II}), \mathrm{Pb}(\mathrm{II})$ and $\mathrm{Cu}$ (II) adsorption by the $\mathrm{AAC}$ and $\mathrm{TiO}_{2}-\mathrm{AAC}$ (see Table 4). The isotherms were compared using the correlation coefficient $R^{2}, \operatorname{SSE}$ and $X^{2}$. Of all the fitted isotherms (Langmuir, Freundlich, Temkin and D-R models), the Langmuir isotherm best described the adsorption process by the two adsorbents, depicting a homogenous and monolayer coverage by the $\mathrm{AAC}$ and $\mathrm{TiO}_{2}-\mathrm{AAC}$. The $R^{2}$ values were between 0.997 and unity for $\mathrm{AAC}$, between
0.999 and unity also for $\mathrm{TiO}_{2}-\mathrm{AAC}$. The monolayer adsorption capacities between 0.192 and $3.957 \mathrm{mg} / \mathrm{g}$ were obtained for AAC while between 2.00 and $3.988 \mathrm{mg} / \mathrm{g}$ respectively. The improvement in the values obtained from $\mathrm{TiO}_{2}-\mathrm{AAC}$ could be attributed to the modification on the surface by $\mathrm{TiO}_{2}$ which improved the surface area based on the synergistic effect of the combined adsorbents (Abunah et al. 2019). The value of the dimensionless equilibrium parameter $\left(R_{L}\right)$ calculated as shown in Table 4 , for $\mathrm{Mn}(\mathrm{II}), \mathrm{Fe}(\mathrm{II})$ and $\mathrm{Cu}$ (II) ions shows that the adsorption process was favourable $\left(0<R_{L}<1\right)$ (Miyah et al. 2017) except for $\mathrm{Pb}$ (II) ion on $\mathrm{TiO}_{2}-\mathrm{AAC}$, whose value of 1.9, depicting that, $\mathrm{Pb}$ ion adsorption onto $\mathrm{AAC}-\mathrm{TiO}_{2}$ was not so favourable. The lowest values obtained from the error analysis of the Langmuir model, by the statistical parameters ( $X^{2}$ and SSE) also validated the fitness of the Langmuir model when compared with the Freundlich, Temkin and D-R model. According to Langmuir isotherm, this means that: (i) it was not possible for adsorption of three the metal to advance outside monolayer coverage. (ii) the active sites on the surface of AAC and $\mathrm{TiO}_{2}$-AAC were equivalent and only take a molecule of the adsorbate. (iii) the ability of heavy metal molecules to

Table 4 Isotherm parameters for heavy metals removal from mining wastewater onto AAC and $\mathrm{AAC}-\mathrm{TiO}_{2}$

\begin{tabular}{|c|c|c|c|c|c|c|c|c|}
\hline & \multicolumn{4}{|l|}{ AAC } & \multicolumn{4}{|l|}{$\mathrm{TiO}_{2}-\mathrm{AAC}$} \\
\hline & $\mathrm{Mn}(\mathrm{II})$ & $\mathrm{Fe}(\mathrm{III})$ & $\mathrm{Cu}(\mathrm{II})$ & $\mathrm{Pb}(\mathrm{II})$ & $\mathrm{Mn}(\mathrm{II})$ & $\mathrm{Fe}(\mathrm{III})$ & $\mathrm{Cu}(\mathrm{II})$ & $\mathrm{Pb}(\mathrm{II})$ \\
\hline \multicolumn{9}{|l|}{ Langmuir } \\
\hline$q_{\mathrm{m}}(\mathrm{mg} / \mathrm{g})$ & 0.783 & 3.957 & 0.149 & 0.019 & 0.678 & 3.989 & 0.169 & 0.002 \\
\hline$K_{\mathrm{L}}(\mathrm{L} / \mathrm{min})$ & 120.491 & 4211.67 & 278.846 & 16.525 & 25.618 & $83,566.7$ & 280.009 & 4.805 \\
\hline$R_{L}$ & $1.94 \mathrm{E}-03$ & $1.19 \mathrm{E}-05$ & $3.69 \mathrm{E}-03$ & 0.240 & $9.18 \mathrm{E}-03$ & $5.98 \mathrm{E}-07$ & $3.67 E-03$ & 1.984 \\
\hline$R^{2}$ & 1 & 1 & 0.9968 & 0.999 & 0.9993 & 1 & 0.9994 & 0.7925 \\
\hline SSE & $1.95 \mathrm{E} 0-3$ & $1.74 \mathrm{E}-03$ & $2.08 \mathrm{E}-03$ & 3.04E04 & $1.92 \mathrm{E}-02$ & $2.00 \mathrm{E}-04$ & $3.89 \mathrm{E}-04$ & $3.02 \mathrm{E}-04$ \\
\hline$X^{2}$ & $2.50 \mathrm{E}-03$ & $4.40 \mathrm{E}-04$ & $1.39 \mathrm{E}-02$ & $1.55 \mathrm{E}-02$ & $2.83 \mathrm{E}-02$ & $5.03 \mathrm{E}-05$ & $2.30 \mathrm{E}-03$ & $1.86 \mathrm{E}-01$ \\
\hline \multicolumn{9}{|l|}{ Freudlich } \\
\hline$N$ & 21.645 & 312 & 7.337 & 1.2274 & 9.259 & 312.5 & 16.077 & 0.222 \\
\hline$K_{f}(\mathrm{mg} / \mathrm{g})$ & 0.759 & 3.948 & 0.123 & 0.007 & 0.152 & $2.205 \mathrm{E}-05$ & 1 & 1 \\
\hline$R^{2}$ & 0.998 & 0.858 & 0.970 & 0.999 & 0.9818 & 0.993 & 0.963 & 0.923 \\
\hline SSE & 1.216 & 6.894 & 5.240 & 24.469 & 1.4011 & 6.907 & 2.862 & 11.537 \\
\hline$X^{2}$ & 4.412 & 5.020 & 2.502 & 4.984 & 3.813 & 5.024 & 1.522 & 10.760 \\
\hline \multicolumn{9}{|l|}{ Temkin } \\
\hline$b_{T}(\mathrm{~kJ} / \mathrm{mol})$ & $-30,387.7$ & $-195,282$ & $-110,489$ & $-91,605.2$ & $-30,387.7$ & $-195,282$ & $-222,933$ & $-50,585.18$ \\
\hline$A_{T}(\mathrm{~L} / \mathrm{g})$ & $2.13 \mathrm{E}-09$ & $9.52 \mathrm{E}-13$ & $5.90 \mathrm{E}-03$ & 2.032 & $2.42 \mathrm{E}-04$ & $7.65 E-13$ & $1.73 \mathrm{E}-06$ & $3.21 \mathrm{E}-01$ \\
\hline$R^{2}$ & 0.999 & 0.858 & 0.975 & 0.999 & 0.895 & 0.993 & 0.967 & 0.998 \\
\hline SSE & 0.007 & $2.874 \times 10-4$ & 0.0013 & $9.030 \times 10-7$ & 0.007 & $2.874 \times 10-4$ & 0.0013 & $9.030 \times 10-7$ \\
\hline$X^{2}$ & $9.49 \times 10^{-4}$ & $7.185 \times 10^{-5}$ & $2.604 \times 10^{-4}$ & $1.300 \times 10^{-7}$ & $9.49 \times 10^{-4}$ & $7.185 \times 10^{-5}$ & $2.604 \times 10^{-4}$ & $1.300 \times 10^{-7}$ \\
\hline \multicolumn{9}{|l|}{$D-R$} \\
\hline$K_{a d}$ & 0.2495 & 1.358 & 1.973 & 4.295 & 0.3691 & 1.3788 & 1.7333 & 8.9582 \\
\hline$R^{2}$ & 0.996 & 0.543 & 0.9299 & 0.9978 & 0.9419 & 0.9864 & 0.9341 & 0.9072 \\
\hline$E$ & 1.416 & 0.607 & 0.503 & 0.341 & 1.164 & 0.602 & 0.537 & 0.236 \\
\hline SSE & 0.029 & $5.64 \times 10^{-5}$ & 0.190 & 0.210 & 0.032 & $3.24 \times 10^{-5}$ & 0.169 & 0.212 \\
\hline$X^{2}$ & 0.004 & $1.14 \times 10-5$ & 0.027 & 0.029 & 0.005 & $1.159 \times 10-5$ & 0.038 & 0.031 \\
\hline
\end{tabular}


adsorb at a specified site is not dependent on the accommodation of the neighbouring site (Ait Ahsaaine et al. 2018).

As shown in Table 4, it can be observed that $\mathrm{TiO}_{2}-\mathrm{AAC}$ was determine to be more efficient for the sorption of heavy metals from the raw mining wastewater with a removal percentage (91.99\%) higher than that of Guillaume et al. (2018) who used titanium oxide clay to adsorb $27.05 \% \mathrm{Cd}$ ion. Most of the adsorption process kinetics agrees with the PSO kinetics model and Langmuir isotherm except for Mustapha et al. (2019) whose kinetics and isotherm followed Avrami, Jovanovic and Redlich-Peterson models, respectively. Other studies with higher values of adsorptive capacity than the presented in Table 4, used simulated wastewater, which did not involve (multiple competition among the heavy metal ions). Similarly, Martinez-Vargas et al. (2018) also reported the fitness of their experimental data to Freundlich isotherm, whereas other studies corroborate with the Langmuir isotherm model as also obtained in this research.

\section{Adsorption Kinetics of $\mathrm{Mn} \mathrm{Fe}, \mathrm{Pb}$ and $\mathrm{Cu}$ ions from mining wastewater onto $\mathrm{AAC}$ and $\mathrm{TiO}_{2}-\mathrm{AAC}$.}

The results of the kinetics of $\mathrm{Mn}$ (II), Fe (III), $\mathrm{Cu}$ (II) and $\mathrm{Pb}$ (II) ions adsorption onto $\mathrm{AAC}$ and $\mathrm{TiO}_{2}-\mathrm{AAC}$ using PFO, PSO, Intra-particle Diffusion and Elovich Kinetics models are presented in Table 5. From the table,

Table 5 Kinetics parameters for AMD ions adsorption onto $\mathrm{AAC}$ and $\mathrm{TiO}_{2}-\mathrm{AAC}$

\begin{tabular}{|c|c|c|c|c|c|c|c|c|}
\hline \multirow[t]{2}{*}{ Parameters } & \multicolumn{4}{|l|}{ AAC } & \multicolumn{4}{|c|}{$\mathrm{TiO}_{2}-\mathrm{AAC}$} \\
\hline & $\mathrm{Mn}(\mathrm{II})$ & $\mathrm{Fe}(\mathrm{III})$ & $\mathrm{Pb}$ (II) & $\mathrm{Cu}$ (II) & Mn (II) & $\mathrm{Fe}$ (III) & $\mathrm{Pb}$ (II) & $\mathrm{Cu}(\mathrm{II})$ \\
\hline \multicolumn{9}{|c|}{ Pseudo first order } \\
\hline$R^{2}$ & 0.9237 & 0.5188 & 0.8836 & 0.875 & 0.7202 & 0.8555 & 0.5117 & 0.9022 \\
\hline$K_{1}(\mathrm{~g} / \mathrm{mg} / \mathrm{min})$ & 0.0304 & 0.0325 & 0.0308 & 0.0619 & 0.0249 & 0.0481 & 0.0456 & 0.042 \\
\hline$q_{e, \exp }(\mathrm{mg} / \mathrm{g})$ & 0.8162 & 3.999 & 0.189 & 0.0186 & 0.8272 & 4.0026 & 0.195 & 0.037 \\
\hline$q_{e, \mathrm{cal}}(\mathrm{mg} / \mathrm{g})$ & 0.1306 & 0.1362 & 0.0166 & 0.449 & 0.8296 & 4.0032 & 0.2022 & 0.0375 \\
\hline SSE & 0.4851 & 14.920 & 0.0317 & 0.1703 & 0.6201 & 10.873 & 0.0136 & 0.0042 \\
\hline$X^{2}$ & 3.7139 & 109.51 & 1.905 & 0.3787 & 21.595 & 15.4208 & 0.0447 & 0.0501 \\
\hline \multicolumn{9}{|c|}{ Pseudo second order } \\
\hline$R^{2}$ & 0.9999 & 1 & 0.9967 & 0.9930 & 0.9987 & 1 & 0.9998 & 0.8172 \\
\hline$K_{2}(\mathrm{~g} / \mathrm{mg} / \mathrm{min})$ & 1.6569 & 2.1971 & 0.7396 & 8.1803 & 0.2566 & 1.9363 & 3.0172 & 1.1580 \\
\hline$q_{e}$,exp $(\mathrm{mg} / \mathrm{g})$ & 0.8162 & 3.999 & 0.189 & 0.0186 & 0.8272 & 4.0026 & 0.195 & 0.037 \\
\hline$q_{e},_{\mathrm{c}}(\mathrm{mg} / \mathrm{g})$ & 0.8296 & 4.0032 & 0.2022 & 0.0375 & 0.8335 & 4.0048 & 0.189 & 0.018 \\
\hline SSE & $5.76 \mathrm{E}-06$ & $1.76 \mathrm{E}-05$ & $5.24 \mathrm{E}-05$ & $3.08-07$ & 0.0137 & 0.0004 & $3.6 \mathrm{E}-05$ & 0.0002 \\
\hline$X^{2}$ & $6.943 \mathrm{E}-06$ & $4.41 \mathrm{E}-06$ & $2.59 \mathrm{E}-04$ & $8.22 \mathrm{E}-06$ & 0.0165 & $9.993 \mathrm{E}-05$ & 0.00019 & 0.0105 \\
\hline \multirow[t]{2}{*}{ Parameters } & \multicolumn{4}{|l|}{$\mathrm{AAC}$} & \multicolumn{4}{|c|}{$\mathrm{TiO}_{2}-\mathrm{AAC}$} \\
\hline & $\mathrm{Mn}$ & $\mathrm{Fe}$ & $\mathrm{Pb}$ & $\mathrm{Cu}$ & $\mathrm{Mn}$ & $\mathrm{Fe}$ & $\mathrm{Pb}$ & $\mathrm{Cu}$ \\
\hline \multicolumn{9}{|l|}{ Intraparticle } \\
\hline$R^{2}$ & 0.5607 & 0.5437 & 0.7814 & 0.664 & 0.6928 & 0.5406 & 0.6192 & 0.9634 \\
\hline$K_{\text {int }}(\mathrm{g} / \mathrm{mg} / \mathrm{min})$ & 0.0468 & 0.2247 & 0.0128 & 0.0022 & 0.0503 & 0.2242 & 0.0111 & 0.0015 \\
\hline$q_{e}, \exp (\mathrm{mg} / \mathrm{g})$ & 0.8162 & 3.999 & 0.189 & 0.0186 & 0.8272 & 4.0026 & 0.195 & 0.037 \\
\hline $\mathrm{C}(\mathrm{mg} / \mathrm{g})$ & 0.333 & 1.654 & 0.053 & 0.013 & 0.268 & 1.660 & 0.070 & 0.001 \\
\hline SSE & 0.244 & 5.500 & 0.020 & 0.001 & 0.313 & 5.469 & 0.015 & 0.001 \\
\hline$X^{2}$ & 0.733 & 3.326 & 0.384 & 0.046 & 1.171 & 3.293 & 0.223 & 1.638 \\
\hline \multirow[t]{2}{*}{ Parameters } & \multicolumn{4}{|l|}{ AAC } & \multicolumn{4}{|c|}{$\mathrm{TiO}_{2}-\mathrm{AAC}$} \\
\hline & Mn (II) & $\mathrm{Fe}$ (III) & $\mathrm{Pb}$ (II) & $\mathrm{Cu}$ (II) & Mn (II) & $\mathrm{Fe}$ (III) & $\mathrm{Pb}$ (II) & $\overline{\mathrm{Cu} \text { (II) }}$ \\
\hline \multicolumn{9}{|l|}{ Elovic } \\
\hline$R^{2}$ & 0.816 & 0.828 & 0.962 & 0.901 & 0.973 & 0.824 & 0.957 & 0.759 \\
\hline$\alpha\left(\mathrm{g} / \mathrm{mg} / \mathrm{min}^{2}\right)$ & 1.836 & 0.366 & 0.052 & 0.013 & 10.143 & 1.068 & 0.028 & 0.002 \\
\hline$\beta(\mathrm{g} / \mathrm{mg} / \mathrm{min})$ & 1.361 & 6.583 & 26.455 & 144.927 & 6.139 & 1.358 & 25.381 & 178.57 \\
\hline$q_{e},_{\mathrm{cal}}(\mathrm{mg} / \mathrm{g})$ & 0.673 & 0.133 & 0.012 & 0.004 & 0.674 & 0.274 & 0.013 & 0.005 \\
\hline SSE & 0.023 & 14.941 & 0.033 & 0.001 & 0.024 & 13.876 & 0.043 & 0.002 \\
\hline$X^{2}$ & 0.035 & 11.746 & 2.640 & 0.242 & 0.035 & 50.641 & 3.328 & 0.342 \\
\hline
\end{tabular}


coefficient of regression $\left(R^{2}\right)$ values for the PSO model of $\mathrm{Mn}$ (II), $\mathrm{Fe}$ (III) and $\mathrm{Cu}$ (II) ions were closer to unity compared with the other models. Also, lower SSE and $\left(X^{2}\right)$ error values obtained for the PSO model specify noteable agreement between the experimental $\left(q_{e}\right.$ exp $)$ and the calculated $\left(q_{e}\right.$,exp $)$ adsorption capacity results. Furthermore, the PSO model gave a higher rate constant $\left(k_{2}\right)$ value than the PSO rate constant $\left(k_{1}\right)$, which signifies a fast adsorption rate at the early contact time. The results obtained, therefore, suggest that the mechanism of adsorption of $\mathrm{Mn}$ (II), $\mathrm{Fe}$ (III) and $\mathrm{Cu}$ (II) ions from mining wastewater is PSO kinetics controlled, which is a chemisorption phenomenon driven. On the contrary, the $\mathrm{Pb}$ (II) ions adsorption from the mining wastewater onto the $\mathrm{AAC}$ and $\mathrm{TiO}_{2}-\mathrm{AAC}$ adsorbent was better explained using the intraparticle diffusion model as a result of its high value of $R^{2}(0.933)$. The lower SSE and $X^{2}$ show a good correlation between the experimental $\left(q_{e}\right.$,exp $)$ and the calculated $\left(q_{e}\right.$,exp $)$ adsorption capacity with this model. The $q_{\mathrm{e}}$ values obtained for AAC are higher than the value obtained when natural clay was used by Khan et al. (2019) and Mustapha et al. (2019). This confirms that the AAC adsorbent is more efficient than other clays reported in the literature (Khan et al., 2019; Mustapha et al. 2019). The obtained PSO model agrees with several reported adsorption studies on $\mathrm{TiO}_{2}$ composites (Kris Tri et al. 2019; Morsy 2017; Nouh et al. 2019).

\section{Adsorption thermodynamics}

The thermodynamic parameters of Mn (II), Fe (III), $\mathrm{Pb}$ (II) and $\mathrm{Cu}$ (II) ions adsorption onto the $\mathrm{AAC}$ and $\mathrm{TiO}_{2}$-AAC adsorbents are displayed in Table 6. From Table 6 , the value of $\Delta \mathrm{G}^{\circ}$ results at $313,323,333,343$ and $353 \mathrm{~K}$ were negative. The negative values imply that the adsorption of $\mathrm{Mn}$ (II), $\mathrm{Fe}$ (III), $\mathrm{Pb}$ (II) and $\mathrm{Cu}$ (II) ions onto the $\mathrm{AAC}$ and $\mathrm{TiO}_{2}-\mathrm{AAC}$ adsorbents were both feasible and spontaneous (Egbosiuba et al. 2019). The change in enthalpy $\left(\Delta \mathrm{H}^{\circ}\right)$ positive values shows that the adsorption process is endothermic (Ogbu et al. 2019). More so, the enthalpy values obtained for $\mathrm{Mn}$ (II), $\mathrm{Fe}$ (II) and $\mathrm{Cu}$ (II) ions was greater than $40 \mathrm{~kJ} / \mathrm{mol}$ (Miyah et al. 2017), implying that the reaction between the adsorbent and the adsorbate solution was chemically controlled (chemisorption), while enthalpy values for $\mathrm{Cu}$ (II) ions deviated from that of previous. (Khulbe and Matsuura 2019). The negative values obtained for entropy change $(\Delta S)$ for the adsorption of $\mathrm{Mn}$ (II), Fe (III), $\mathrm{Cu}$ (II) and $\mathrm{Pb}$ (II) ions onto the $\mathrm{AAC}$ and $\mathrm{TiO}_{2}-\mathrm{AAC}$ suggest a reduction in the degree of randomness at the adsorbent/adsorbate interface during the adsorption process.

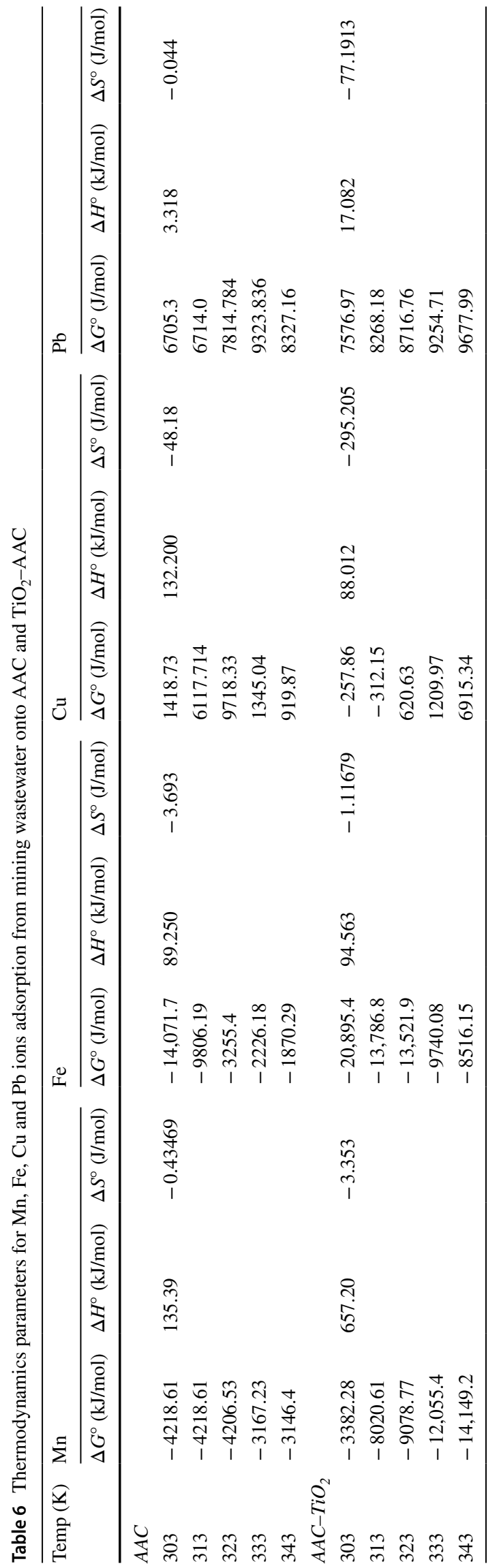




\section{Comparison of adsorption parameters of $\mathrm{AAC}$ and $\mathrm{TiO}_{2}-$ AAC with literature}

Table 7 shows the comparison of adsorption parameters of $\mathrm{AAC}$ and $\mathrm{TiO}_{2}-\mathrm{AAC}$ for $\mathrm{Pb}$ (II), $\mathrm{Cu}$ (II), $\mathrm{Mn}$ (II) and $\mathrm{Fe}$ (III) ions, with the available data in the literature. For the adsorption of the $\mathrm{Mn}$ (II) ion, it was observed that $\mathrm{TiO}_{2}-\mathrm{AAC}$ (89.34\%) performed better than the AAC $(83.12 \%)$. This may be due to the modification of the AAC by $\mathrm{TiO}_{2}$ nanoparticles. However, Motsi et al. (2009) found that Zeolite removes Mn (II) ions more efficiently (95.20\%) than both the $\mathrm{AAC}$ and $\mathrm{TiO}_{2}-\mathrm{AAC}$, although at a higher contact time of $360 \mathrm{~min}$. This corroborates the findings of Marque et al. (2013) which revealed that the manganese removal increased with the increase in contact time until it reaches equilibrium. As shown in the table, all other adsorbents have a low efficiency of below $50 \%$ for Mn (II) ion removal. This justifies that the adsorbents in this study were efficient for the removal of $\mathrm{Mn}$ (II) ion at a lesser contact time of $120 \mathrm{~min}$ than that of the Zeolite (360 min). Also, both the AAC and $\mathrm{TiO}_{2}-\mathrm{AAC}$ absorbents effectively remove $\mathrm{Fe}$ (III) ion from the mining wastewater at 86.45 and $91.99 \%$, respectively, however, $\mathrm{TiO}_{2}-\mathrm{AAC}$ performed better. Other adsorbents shown in the table such as zeolite, $\mathrm{Ha}-\mathrm{TiO}_{2}$ and cellulosic waste gave adsorbent efficiency of 59.5, 14.80 and $8.70 \%$, respectively, for Fe (III) ion removal, which are below the values obtained in this study. The adsorption efficiency of $\mathrm{Cu}$ (II) unto AAC and $\mathrm{TiO}_{2}-\mathrm{AAC}$ as shown in the table was 68.47 and $81.94 \%$, respectively. This shows that the AAC and $\mathrm{TiO}_{2}-\mathrm{AAC}$ removed $\mathrm{Cu}$ (II) ions from the wastewater more efficiently than some adsorbents reported in the literature (Budsaereechai et al. 2012; Sdiri et al. 2014). However, some other adsorbents such as anatase-rutile $\mathrm{TiO}_{2}$ and anatase-rutile $\mathrm{TiO}_{2}$-clay performed more efficiently than those investigated in this study, as shown in the table (Georgaka and Spanos 2010; Guillaume et al. 2018). This may be due to the surface area of respective adsorbents obtained from different clay sources. In addition, the contact time of the adsorption process could also be responsible for the increase in the removal percentage of $\mathrm{Cu}$ (II) ion as Guillaume et al. (2018) attained higher percentage removal of $91.19 \% \mathrm{Cu}$ (II) ion at $240 \mathrm{~min}$ as against $120 \mathrm{~min}$ in this study. Therefore, the shorter contact time to remove $\mathrm{Cu}$ (II) ion indicate the efficacy of the adsorbents (AAC and $\mathrm{TiO}_{2}-\mathrm{AAC}$ ) investigated in this study. As the contact time plays a vital role in the adsorption process, which implies that a shorter interaction time in attaining equilibrium adsorption reduces the operational cost and the operating time (Rudi et al. 2020). From the table, $\mathrm{Pb}$ (II) ion was the least adsorbed compare to other heavy metals, as the AAC and $\mathrm{TiO}_{2}-\mathrm{AAC}$ removed $29.48 \%$ and $32.39 \%$, respectively. This is due to ionic radii of $\mathrm{Pb}$ (II) ion $(0.119 \mathrm{~nm})$ which is more than those of Fe (III) $(0.060 \mathrm{~nm}), \mathrm{Mn}$ (II) $(0.070 \mathrm{~nm})$ and $\mathrm{Cu}$ (II) $(0.073 \mathrm{~nm})$ ions. As the $\mathrm{Pb}$ (II) ion has the least chance to be incorporated into $\mathrm{AAC}$ and $\mathrm{TiO}_{2}-\mathrm{AAC}$ structures compared with cations with smaller ionic radii (Mobasherpour et al., 2012). Generally, the $\mathrm{TiO}_{2}-\mathrm{AAC}$ adsorbent revealed greater efficiency for the adsorption process as it was able to sequester multi ions from the mining wastewater in the order of $\mathrm{Fe}$ (III) $>\mathrm{Mn}$ (II) $>\mathrm{Cu}$ (II) $>\mathrm{Pb}$ (II). This is possible due to the improved surface area of the $\mathrm{TiO}_{2}-\mathrm{AAC}$ adsorbent by the rutile- $\mathrm{TiO}_{2}$ nanoparticle. Worthy of note is that the $\mathrm{TiO}_{2}-\mathrm{AAC}$ adsorbent removed multi ions from the mining wastewater efficiently compared to other similar adsorbents identified in the table, hence, the novelty of this study.

\section{Adsorption mechanism of $\mathrm{AAC}$ and $\mathrm{TiO}_{2}-\mathrm{AAC}$}

Usually, mechanism of the heavy metal ions adsorption onto the nano adsorbents is greatly influenced by the surface chemistry of the adsorbent, the ionic charge on the metal ions and the adsorbate interactions (Miyah et al. 2017). From this research, the adsorption of $\mathrm{Mn}$ (II), $\mathrm{Fe}$ (III), $\mathrm{Pb}$ (II) and $\mathrm{Cu}$ (II) ions onto $\mathrm{AAC}$ and $\mathrm{TiO}_{2}$-AAC was reliant on on the $\mathrm{pH}$ and ionic strength. Figure 11 provides information about the mechanism of the metal ions adsorption onto the two adsorbents. It can be seen that adsorption of heavy metal ions onto $\mathrm{AAC}$ and $\mathrm{TiO}_{2}-\mathrm{AAC}$ was favoured by low $\mathrm{pH}$ $\left(\mathrm{pH}>\mathrm{pH}_{\mathrm{PZC}}\right)$ values below 8.0 for $\mathrm{AAC}$ and values below 10.0 for $\mathrm{TiO}_{2}-\mathrm{AAC}$ point of zero charges, which resulted in the high amount of $\mathrm{Mn}$ (II), $\mathrm{Fe}$ (III), and $\mathrm{Pb}$ (II) ions adsorbed.

This was attributed to the strong intermolecular electrostatic attraction between the negatively charged adsorbate in mining wastewater and the positively charged $\mathrm{AAC}$ and $\mathrm{TiO}_{2}-\mathrm{AAC}$ surface.

Nevertheless, at higher $\mathrm{pH}\left(\mathrm{pH}>\mathrm{pH}_{\mathrm{PZC}}\right)(>8$ for AAC and $>10$ for $\mathrm{TiO}_{2}-\mathrm{AAC}$ ), limited number of metal ions was adsorbed by $\mathrm{AAC}$ and $\mathrm{TiO}_{2}-\mathrm{AAC}$ due to increase electronegativity $(\mathrm{pH})$ of the adsorbate solution at the surface of the adsorbents. This reduces the susceptibility of the positive metal ions (Mn (II), Fe (III), Pb (II) and $\mathrm{Cu}$ (II)) adsorption because of electrostatic repulsion (Egbosiuba et al. 2019). Other adsorption mechanisms such as; ion exchange or hydrophobic bonding instead of electrostatic interactions may also be responsible for the heavy metal adsorption onto the $\mathrm{AAC}$ and $\mathrm{TiO}_{2}-\mathrm{AAC}$ surface.

\section{Conclusion}

Rutile-titanium dioxide nanoparticles were successfully synthesised via the green synthesis method, using the aqueous leaf extract of Parkia biglobossa. The $\mathrm{TiO}_{2}$ was anchored on acid-activated kaolinite clay and subjected to comparative

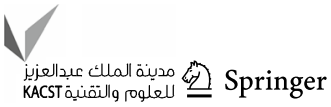


Table 7 Adsorption parameters of $\mathrm{AAC}, \mathrm{TiO}_{2}-\mathrm{AAC}$ and other adsorbents in literature

\begin{tabular}{|c|c|c|c|c|c|c|c|c|c|}
\hline Adsorbents & $\begin{array}{l}\mathrm{TiO}_{2} \text { Precur- } \\
\text { sors }\end{array}$ & $\mathrm{TiO}_{2}$ Phase & $\begin{array}{l}\text { Initial } \\
\text { conc. } \\
\mathrm{C}_{\mathrm{o}}(\mathrm{mg} / \mathrm{L})\end{array}$ & $\begin{array}{l}\text { Contact } \\
\text { Time } \\
(\min )\end{array}$ & $\begin{array}{l}\text { Adsorbent } \\
\text { Dosage } \\
(\mathrm{g})\end{array}$ & $\begin{array}{l}\text { Surface area } \\
\mathrm{m}^{2} / \mathrm{g}\end{array}$ & $\begin{array}{l}\text { Crystal- } \\
\text { lite size } \\
(\mathrm{nm})\end{array}$ & Efficiency (\%) & References \\
\hline \multicolumn{10}{|l|}{$M n(I I)$} \\
\hline $\mathrm{Ha}-\mathrm{TiO}_{2}$ & $\mathrm{TiCl}_{4}$ & Anatase & 300 & 15 & 0.05 & 449 & - & 24.92 & $\begin{array}{l}\text { Kanna et al. } \\
(2005)\end{array}$ \\
\hline Zeolite & Clinoptilolite & - & 400 & 360 & 3.7 & - & - & 95.20 & $\begin{array}{l}\text { Motsi et al. } \\
\text { (2009) }\end{array}$ \\
\hline $\begin{array}{l}\text { Graphene- } \\
\text { Zinc oxide } \\
\text { Nps }\end{array}$ & - & - & 10.5 & 20 & 25.06 & - & - & 34.10 & $\begin{array}{l}\text { Leiva et al. } \\
\text { (2021) }\end{array}$ \\
\hline $\begin{array}{l}\text { White rice } \\
\text { husk }\end{array}$ & Organic & - & 100 & 480 & 2.5 & - & 50,000 & 26.60 & $\begin{array}{l}\text { Tavlieva et al. } \\
\text { (2015) }\end{array}$ \\
\hline AAC & - & & 0.943 & 120 & 0.5 & 14.15 & 8.10 & 83.12 & This study \\
\hline $\mathrm{TiO}_{2}-\mathrm{AAC}$ & - & & 0.943 & 120 & 0.5 & 32.98 & 6.11 & 89.34 & This study \\
\hline \multicolumn{10}{|l|}{$\mathrm{Fe}(I I I)$} \\
\hline Zeolite & Clinoptilolite & - & 400 & 360 & 3.7 & - & - & 59.50 & $\begin{array}{l}\text { Motsi et al. } \\
\text { (2009) }\end{array}$ \\
\hline $\mathrm{Ha}-\mathrm{TiO}_{2}$ & $\mathrm{TiCl}_{4}$ & Anatase & 300 & 15 & 0.05 & 449 & - & 14.80 & $\begin{array}{l}\text { Kanna et al. } \\
\text { (2005) }\end{array}$ \\
\hline $\begin{array}{l}\text { Cellulosic } \\
\text { waste }\end{array}$ & $\begin{array}{l}\text { Organic mate- } \\
\text { rials }\end{array}$ & - & 4000 & 1440 & 2 & 2.66 & - & 8.70 & $\begin{array}{l}\text { Genty et al. } \\
\text { (2017) }\end{array}$ \\
\hline AAC & - & & 20.02 & 120 & 0.5 & 14.15 & 8.10 & 86.45 & This study \\
\hline $\mathrm{TiO}_{2}-\mathrm{AAC}$ & - & & 20.02 & 120 & 0.5 & 32.98 & 6.11 & 91.99 & This study \\
\hline \multicolumn{10}{|l|}{$C u(I I)$} \\
\hline $\mathrm{Ag} / \mathrm{Ti} /$ clay & - & & 200 & - & - & - & - & 97.50 & $\begin{array}{l}\text { Ajenifuja et al. } \\
\text { (2016) }\end{array}$ \\
\hline Clay- $\mathrm{TiO}_{2}$ & $\mathrm{TiO}_{2}$ & $A-R$ & 100 & 240 & 0.1 & 50 & 30 & 91.19 & $\begin{array}{l}\text { Guillaume et al. } \\
\text { (2018) }\end{array}$ \\
\hline Raw clay & - & - & 1000 & 60 & 1 & 17.84 & - & 3.07 & $\begin{array}{l}\text { Sdiri et al. } \\
\text { (2014) }\end{array}$ \\
\hline Bentonite & - & & 10 & 60 & 0.5 & - & - & 76.88 & $\begin{array}{l}\text { Hussain and Ali } \\
\text { (2021) }\end{array}$ \\
\hline $\mathrm{TiO}_{2}$ & $\mathrm{TIO}_{2}$ & $A-R$ & 1.28 & 30 & 0.5 & 50 & 30 & 99.90 & $\begin{array}{l}\text { Georgaka and } \\
\text { Spanos }(2010)\end{array}$ \\
\hline Raw clay & Bentonite & - & 2000 & 864 & 1 & 47 & - & 25.40 & $\begin{array}{l}\text { Budsaereechai } \\
\text { et al. (2012) }\end{array}$ \\
\hline $\mathrm{Ag} / \mathrm{Ti} /$ clay & - & & 1000 & 288 & 0.12 & - & - & 91.50 & $\begin{array}{l}\text { Ajenifuja et al. } \\
\text { (2016) }\end{array}$ \\
\hline Activated clay & - & & 2000 & 864 & 1 & 74 & - & 29.97 & $\begin{array}{l}\text { Budsaereechai } \\
\text { et al. (2012) }\end{array}$ \\
\hline AAC & - & & 0.943 & 120 & 0.5 & 14.15 & 8.10 & 68.47 & This study \\
\hline $\mathrm{TiO}_{2}-\mathrm{AAC}$ & - & & 0.943 & 120 & 0.5 & 32.98 & 6.11 & 81.94 & This study \\
\hline \multicolumn{10}{|l|}{$P b(I I)$} \\
\hline $\mathrm{LAO}-\mathrm{TiO}_{2}$ & $\mathrm{TiCl}_{4}$ & & 50.00 & 1440 & 0.25 & - & - & 4.40 & Bijang 2020 \\
\hline Bentonite & Local & & 10 & 60 & 0.5 & - & - & 75.76 & $\begin{array}{l}\text { Hussain and Ali } \\
\text { (2021) }\end{array}$ \\
\hline Raw clay & Bentonite & - & 2000 & 864 & 1 & 47 & - & 76.50 & $\begin{array}{l}\text { Budsaereechai } \\
\text { et al. (2012) }\end{array}$ \\
\hline Activated clay & - & & 2000 & 864 & 1 & 74 & - & 84.00 & $\begin{array}{c}\text { Budsaereechai } \\
\text { et al. (2012) }\end{array}$ \\
\hline AAC & Kaolin & & 0.94 & 120 & 0.5 & 32.98 & 8.10 & 29.48 & This study \\
\hline $\mathrm{TiO}_{2}-\mathrm{AAC}$ & TTIP & & 0.94 & 120 & 0.5 & 32.98 & 6.11 & 32.39 & This study \\
\hline
\end{tabular}

They are for emphasis, referring to the present study 


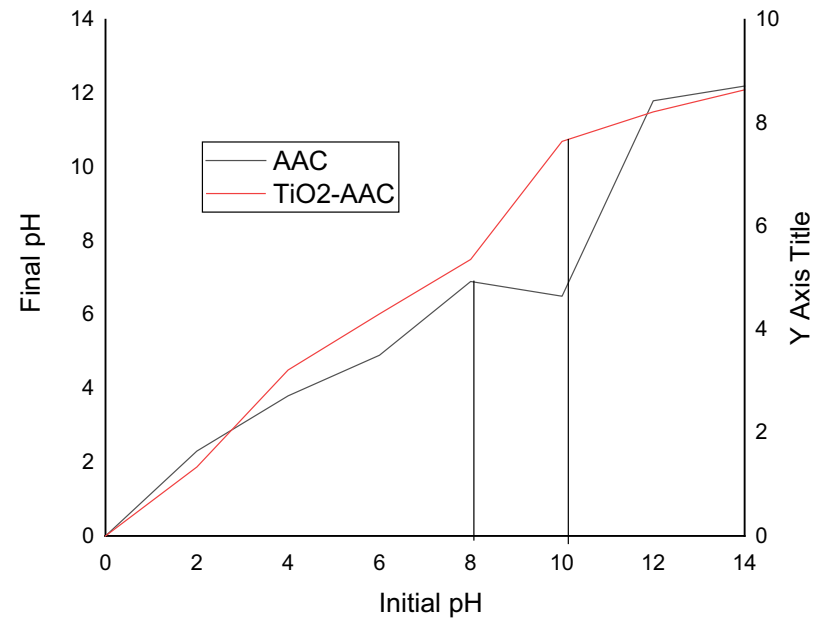

Fig. $11 \mathrm{pH}$ point of zero charges of $\mathrm{AAC}$ and $\mathrm{TiO}_{2}-\mathrm{AAC}$

adsorptive studies with ordinary activated kaolinite clay for the removal of selected heavy metals from mining wastewater. The characterisation study established that the AAC and $\mathrm{TiO}_{2}-\mathrm{AAC}$ are porous adsorbents for the removal of $\mathrm{Mn}$ (II), $\mathrm{Fe}$ (III), $\mathrm{Pb}$ (II) and $\mathrm{Cu}$ (II) ions from the mining wastewater, with $\mathrm{TiO}_{2}-\mathrm{AAC}$ surface more porous than the AAC, due to its modification by $\mathrm{TiO}_{2}$. $\mathrm{TiO}_{2}-\mathrm{AAC}$ has a smaller crystallite size of $6.11 \mathrm{~nm}$ adjudged better than AAC with $8.10 \mathrm{~nm}$ crystallite size. The BET surface area of the adsorbents was also increased from $14.15 \mathrm{~m}^{2} / \mathrm{g}$ (AAC) to $32.98 \mathrm{~m}^{2} / \mathrm{g}$ $\left(\mathrm{TiO}_{2}-\mathrm{AAC}\right)$. The synthesised and the anchored titanium was stable in the +4 oxidation state as revealed by the XPS characterisation. Finest conditions for the removal of the four ions under the applied conditions of $120 \mathrm{~min}$ with $0.5 \mathrm{~g}$ adsorbent dose and $70{ }^{\circ} \mathrm{C}$ were; $83.45 \% \mathrm{Mn}$ (II), $86.13 \% \mathrm{Fe}$ (III), $68.47 \% \mathrm{Cu}$ (II) and $29.39 \% \mathrm{~Pb}$ (II) by AAC and $89.36 \%$ $\mathrm{Mn}$ (II), 91.99\% Fe (III), 81.94\% Cu (II) with $32.39 \% \mathrm{~Pb}$ (II) by $\mathrm{TiO}_{2}-\mathrm{AAC}$. The adsorption of heavy metal ions was also discovered to depend on the ionic strength, surface area and surface functional groups of the adsorbents. The adsorption isotherm and kinetic model showed good agreement with Langmuir and pseudo-second-order model for both AAC and $\mathrm{TiO}_{2}-\mathrm{AAC}$. The thermodynamic parameters confirmed a spontaneous, feasible, less random and chemisorption adsorption process by the adsorbents. The anchoring of $\mathrm{TiO}_{2}$ nanoparticles onto acid-treated kaolinite clay enhanced the percentage removal of the unwanted heavy metals from the mining wastewater compared to AAC alone.

Authors' contribution All the authors were involved in the conceptualization, design of experiments, synthesis, development of adsorbents, application, data analysis and manuscript development in equal measure.

Funding The authors received no specific funding for this work.
Data availability All materials were developed by the authors and data generated through laboratory experiments.

\section{Declarations}

Conflicts of interest There is no conflict of interest.

Ethics approval Not applicable.

Consent for publication All the authors agreed to submit the manuscript in this journal.

Open Access This article is licensed under a Creative Commons Attribution 4.0 International License, which permits use, sharing, adaptation, distribution and reproduction in any medium or format, as long as you give appropriate credit to the original author(s) and the source, provide a link to the Creative Commons licence, and indicate if changes were made. The images or other third party material in this article are included in the article's Creative Commons licence, unless indicated otherwise in a credit line to the material. If material is not included in the article's Creative Commons licence and your intended use is not permitted by statutory regulation or exceeds the permitted use, you will need to obtain permission directly from the copyright holder. To view a copy of this licence, visit http://creativecommons.org/licenses/by/4.0/.

\section{References}

Abdallah S (2019) Remediation of copper and zinc from wastewater by modified clay in Asir region southwest of Saudi Arabia. Open Geosci 11:505-512. https://doi.org/10.1515/geo-2019-0041

Abu-Dalo M, Jaradat A, Albiss BA, Al-Rawashdeh NAF (2019) Green synthesis of TiO2 NPs/pristine pomegranate peel extract nanocomposite and its antimicrobial activity for water disinfection. $\mathrm{J}$ Environ Chem Eng. https://doi.org/10.1016/j.jece.2019.103370

Abunah D, Onindo C, Andala D, Ochoti E (2019) Physico-chemical removal of heavy metals from contaminated water using recyclable montmorillonite cellulose nanocomposite. J Mater Environ Sci 10(12):1349-1361

Acheampong MA, Ansa EDO (2017) Low-cost technologies for mining wastewater treatment. J Environ Sci Eng B(6):391-405. https:// doi.org/10.17265/2162-5263/2017.08.001

Ahamed MI, Inamuddin L, Sharma G, Khan A, Asiri AM (2016) Turmeric/polyvinyl alcohol Th(IV) phosphate electrospun fibers: synthesis, characterization and antimicrobial studies. J Taiwan Inst Chem Eng 68:407-414. https://doi.org/10.1016/j.jtice.2016. 08.024

Ajenifuja E, Ajao JA, Ajayi EOB (2016) Equilibrium adsorption isotherm studies of $\mathrm{Cu}$ (II) and $\mathrm{Co}$ (II) in high concentration aqueous solutions on Ag-TiO2-modified kaolinite ceramic adsorbents. Appl Water Sci. https://doi.org/10.1007/s13201-016-0403-6

Akinnawo S (2019) Synthesis, modification, applications and challenges of titanium dioxide nanoparticles. Res J Nanosci Eng 3(14):10-22

Alaya-Ibrahim S, Kovo AS, Abdulkareem AS, Adeniyi OD, Yahya MD (2019) Development of nano-silver doped zeolite asynthesized from Nigerian Ahoko kaolin for treatment of wastewater of a typical textile company. Chem Eng Commun 9:1-25. https://doi.org/ $10.1080 / 00986445.2019 .1641490$

Al-Essa K, Khalili F (2018) Heavy metals adsorption from aqueous solutions onto unmodified and modified jordanian kaolinite clay: batch and column techniques. Am J Appl Chem 6(1):25

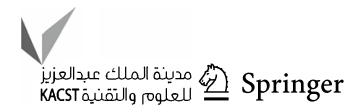


Ashraf S, Siddiqa A, Shahida S, Qaisar S (2019) Titanium-based nanocomposite materials for arsenic removal from water: a review. Heliyon 5(01577):1-8. https://doi.org/10.1016/j.heliyon.2019. e01577

Ayawei N, Ebelegi AN, Wankasi D (2017) Modelling and interpretation of adsorption isotherms. J Chem 2017:3039817. https://doi. org/10.1155/2017/3039817

Balali-Mood M, Naseri K, Tahergorabi Z, Khazdair MR, Sadeghi M (2021) Toxic mechanisms of five heavy metals: mercury. Lead, Chromium, Cadmium, and Arsenic. https://doi.org/10.3389/fphar. 2021.643972

Bankole MT, Abdulkareem AS, Mohammed IA, Ochigbo SS, Tijani JO, Abubakre OK, Roos WD (2019) Selected heavymetals removal from electroplating wastewater by purifiedand polyhydroxylbutyrate functionalized carbon nanotubesadsorbents. Sci Rep 9:1-19. https://doi.org/10.1038/s41598-018-37899-4

Bhateria R, Singh R (2019) A review on nanotechnological application of magnetic iron oxides for heavy metal removal. J Water Process Eng. https://doi.org/10.1016/j.jwpe.2019.100845

Bijang CM, Nurdin M, Azis T, Sekewael SJ, Wattimena H (2020) ouw natural clay-titanium Oksida $(\mathrm{LaO}-\mathrm{TiO} 2)$ composite adsorption ability on lead $(\mathrm{Pb})$ metal. J Phys Conf Ser 1463:012011

Bok-Badura J, Jakóbik-Kolon A, Karoń K, Mitko K (2018) Sorption studies of heavy metal ions on pectin-nano-titanium dioxide composite adsorbent. Sep Sci Technol 53(7):1034-1044. https://doi. org/10.1080/01496395.2017.1329840

Boparai HK, Joseph M, O'Carroll DM (2011) Kinetics and thermodynamics of cadmium ion removal by adsorption onto nano zerovalent iron particles. J Hazard Mater 186(1):458-465

Budsaereechai S, Kamwialisak K, Ngernyen Y (2012) Adsorption of lead, cadmium and copper on natural and acid activated bentonite clay. KKU Res J 17(5):800-810

Bwapa JK, Jaiyeola AT, Chetty R (2017) Bioremediation of acid mine drainage using algae strains: a review. S Afr J Chem Eng 24:62-70

Cardoso BN, Kohlrausch EC, Laranjo MT, Benvenutti EV, Balzaretti NM, Arenas LT, Costa TMH (2019) Tuning anatase-rutile phase transition temperature: $\mathrm{TiO}_{2} / \mathrm{SiO}_{2}$ nanoparticles applied in dyesensitized solar cells. Int J Photoenergy 2019:1-9. https://doi.org/ 10.1155/2019/7183978

Dedehou VF, Olounladé PA, Adenilé DA, Alowanou G, Azando EV, Hounzangbé-Adoté MS (2016) A review on medicinal plants of Parkia Biglobosa (Mimosaceae-Fabaceae) and Pterocarpus Erinaceus (Leguminosae-Papilionoidea). J Med Plants 4(6):132-137

Dubinin MM (1969) The potential theory of adsorption of gastheory of adsorption of gases and vapour. Chem Rev 60:235-241

Durango-Giraldo G, Cardona A, Zapata JF, Santa JF, Buitrago-Sierra R (2019) Titanium dioxide modified with silver by two methods for bactericidal applications. Heliyon 5(5):e01608

Egbosiuba TC, Abdulkareem AS, Kovo AS, Afolabi EA, Tijani JO, Auta M, Roos WD (2019) Ultrasonic enhanced adsorption of methylene blue onto the optimized surface area of activated carbon: adsorption isotherm, kinetics and thermodynamics. Chem Eng Res Des 153:315-336

Esmaeili A, Mobini M, Eslami H (2019) Removal of heavy metals from acid mine drainage by native natural clay minerals, batch and continuous studies. Appl Water Sci 9(97):1-6. https://doi.org/10. 1007/s13201-019-0977-x

Falk GS, Borlaf M, López-Muñoz MJ, Fariñas JC, Rodrigues Neto JB, Moreno R (2018) Microwave-assisted synthesis of $\mathrm{TiO}_{2}$ nanoparticles: photocatalytic activity of powders and thin films. J Nanopart Resour 20(23)

Fu W, Chen H, Yang S, Huang W, Huang Z (2019) Poly(-diallyldimethylammonium-MoS4) based amorphous molybdenum sulphide composite for selectively mercury uptake from wastewater across a large $\mathrm{pH}$ region. Chemosphere 232:9-17. https://doi.org/ 10.1016/j.chemosphere.2019.05.182

Genty T, Bussière B, Benzaazoua M, Neculita CM, Zagury GJ (2017) Iron removal in highly contaminated acid mine drainage using passive biochemical reactors. Water Sci Technol 76(7):18331843. https://doi.org/10.2166/wst.2017.362

Georgaka A, Spanos N (2010) Study of the cu (II) removal from aqueous solutions by adsorption on titania. Global NEST $\mathbf{J}$ 12(3):239-247

Gholipour A, Zahabi H, Stefanakis AI (2020) A novel pilot and fullscale constructed wetland study for glass industry wastewater treatment. Chemopshere. https://doi.org/10.1016/j.chemosphere. 2020.125966

Guillaume PLA, Chelaru A, Visa M, Lassiné O (2018) Titanium oxideclay" as adsorbent and photocatalysts for wastewater treatment. J Membr Sci Technol 8(1):176-186. https://doi.org/10.4172/21559589.1000176

Guo H, Wang W, Liu L, He Y, Li C, Wang Y (2013) Shape-controlled synthesis of $\mathrm{Ag} @ \mathrm{TiO}_{2}$ cage-bell hybrid structure with enhanced photocatalytic activity and superior lithium storage+. Green Chem 15:2810-2816. https://doi.org/10.1039/c3g41280f

Ho YS, McKay G (1999) Pseudo-second order model for sorption processes. Process Biochem 34(5):451-465. https://doi.org/10.1016/ S0032-9592(98)00112-5

Hussain ST, Ali SAK (2021) Removal of heavy metal by ion exchange using bentonite clay. J Ecol Eng 22(1):104-111. https://doi.org/ 10.12911/22998993/128865

Kamal NA, Gooyong L (2019) Removal of selected heavy metals in acid mine drainage using chemical precipitation method. J Adv Res Fluid Mech Therm Sci 57(1):121-130

Kanna M, Wongnawa W, Sherdshoopongse P, Boonsin P (2005) Adsorption behavior of some metal ions on hydrated amorphous titanium dioxide surface. Songklanakarin J Sci Technol 27(5):1017-1026

Kefeni KK, Msagati TAM, Mamba BB (2017) Acid mine drainage: prevention, treatment options, and resource recovery: a review. J Clean Prod 151(2017):475-493

Kenne-Diffo B, Elimbi A, Cyr M, Dika-Manga J, Tchakoute KH (2015) Effect of the rate of calcination of kaolin on the properties of metakaolin-based geopolymers. J Asian Ceram Soc 3(1):130-138

Khan MI, Almesfer MK, Danish M, Ali IH, Shoukry H, Patel R, Rehan M (2019) Potential of Saudi natural clay as an effective adsorbent in heavy metals removal from wastewater. Desalin Water Treat 158:140-151. https://doi.org/10.5004/dwt.2019.24270

Khulbe KC, Matsuura T (2019) Removal of heavy metals and pollutants by membrane adsorption techniques. Appl Water Sci 8(19):130. https://doi.org/10.1007/s13201-018-0661-6

Kris Tri B, Lutfi Aditya H, Elza J (2019) Adsorption of uranium simulation waste using bentonite:titanium dioxide. Urania 25(1):19-31

Krishnan B, Mahalingam S (2017) Ag/TiO2/bentonite nanocomposite for biological applications: synthesis, characterization, antibacterial and cytotoxic investigations. Adv Powder Technol 28:22652280. https://doi.org/10.1016/j.apt.2017.06.007

Lakherwal D (2014) Adsorption of heavy metals: a review. Int J Environ Res Develop 4(1):41-48

Landage KS, Arbade GK, Khanna P, Bhongale CJ (2020) Biological approach to synthesize $\mathrm{TiO} 2$ nanoparticles using Staphylococcus aureus for antibacterial and anti-biofilm applications. J Microbiol Exper 8(1):36-43. https://doi.org/10.15406/jmen.2020.08.00283

Langmuir I (1918) The constitution and fundamental properties of solids and liquids. J Am Chem Soc 38:2221-2295

Leiva E, Tapia C, Rodríguez C (2021) Removal of Mn(II) from acidic waste waters using graphene oxide-Zno nanocomposites. Molecules 26(2713):1-18. https://doi.org/10.3390/molecules26092713 
Li L, Yan J, Wang T, Zhao Z, Gong J, Guan N (2015) Sub-10 nm rutile titanium nanoparticles for efficient visible-light-driven photocatalytic hydrogen production. Nat Commun. https://doi.org/10.1038/ ncomms6881

Liu T, Liu Z, Zhang R, Wang Y, Bruggen B, Wang X (2015) Fabricationofathin film nanocompositehollow fiber nanofiltration membrane for wastewater treatment. J Membr Sci 488:92-102. https:// doi.org/10.1016/j.memsci.2015.04.020

Madadi Z, Soltanieh M, Lotfabad TB, Nazari BS (2020) Green synthesis of titanium dioxide nanoparticles with Glycyrrhiza glabra and their photocatalytic activity. Asian J Green Chem 4(3):256-268. https://doi.org/10.33945/SAMI/AJGC.2020.3.3

Madzivire G, Gitari WM, Vadapalli VRK, Ojumu TV, Petrik LF (2011) Fate of sulphate removed during the treatment of circumneutral mine water and acid mine drainage with coal fly ash: Modelling and experimental approach. Miner Eng 24:1467-1477

Malima N, Lugwisha E, Mwakaboko A (2018) The efficacy of raw Malangali kaolin clay in the adsorptive removal of cadmium and cobalt ions from water. Tanzania J Sci 44(2):64-30

Manisalidis I, Stavropoulou E, Stavropoulos A, Bezirtzoglou E (2020) Environmental and health impacts of air pollution: a review. Front Public Health. https://doi.org/10.3389/fpubh.2020.00014

Marque TL, Alves VN, Coelho LM, Coelho NMM (2013) Assessment of the use of Moringa oleifera seeds for removal of manganese ions from aqueous systems. BioResources 8:2738-2751

Martinez-Vargas S, Martínez AI, Hernandez-Beteta EE, MijangosRicardez OF, Vazquez-Hipolito V, Patino-Carachure C, LopezLuna J (2018) As(III) and As(V) adsorption on manganese ferrite nanoparticles. J Mol Struct 1154:524-534. https://doi.org/10. 1016/j.molstruc.2017.10.076

Masindi V, Muedi KL (2018) Heavy metals. In: Saleh HEDM, Aglan RF (Eds.), Environmental contamination by heavy metals. Accepted from https://www.intechopen.com/books/heavy-metals/ environmental-contamination-by-heavy-metals. https://doi.org/10. 5772/intechopen.76082

Miyah Y, Lahrichi A, Idrissi M, Boujraf S, Taouda H, Zerrouq F (2017) Assessment of adsorption kinetics for removal potential of Crystal Violet dye from aqueous solutions using Moroccan pyrophyllite. J Assoc Arab Univ Basic Appl Sci 23:20-28. https://doi.org/10. 1016/j.jaubas.2016.06.001

Mobasherpour I, Salahi E, Pazouki M (2012) Comparative of the removal of $\mathrm{Pb}^{2+}, \mathrm{Cd}^{2+}$ and $\mathrm{Ni}^{2+}$ by nano crystallite hydroxyapatite from aqueous solutions: Adsorption isotherm study. Arab J Chem 5:439-446. https://doi.org/10.1016/j.arabjc.2010.12.022

Morsy AMA (2017) Performance of magnetic talc titanium oxide composite for thorium ions adsorption from acidic solution. Environ Technol Innov 8:399-410. https://doi.org/10.1016/j.eti.2017.09. 004

Motsi T, Rowson NA, Simmons MJH (2009) Adsorption of heavy metals from acid mine drainage by natural zeolite. Int J Miner Process 92(2009):42-48. https://doi.org/10.1016/j.minpro.2009.02.005

Mungondori HH, Mtetwa S, Tichagwa L, Katwire TM, Nyamukamba P (2017) Synthesis and application of a ternary composite of clay, saw-dust and peanut husks in heavy metal adsorption. Water Sci Technol 12(3):1-11. https://doi.org/10.2166/wst.2017.123

Musial J, Krakowiak R, Mlynarczyk DT, Goslinski T, Stanisz BJ (2020) Titanium dioxide nanoparticles in food and personal care products-What do we know about their safety? Nanomaterials 10(6):1110-1121

Mustapha S, Ndamitso MM, Abdulkareem AS, Tijani JO, Mohammed AK, Shuaib DT (2019) Potential of using kaolin as a natural adsorbent for the removal of pollutants from tannery wastewater. Heliyon 5(e02923):1-17. https://doi.org/10.1016/j.heliyon.2019. e02923

Mustapha S, Ndamitso MM, Abdulkareem AS, Tijani JO, Shuaib DT, Ajala AO, Mohammed AK (2020) Application of $\mathrm{TiO}_{2}$ and
$\mathrm{ZnO}$ nanoparticles immobilized on clay in wastewater treatment: a review. Appl Water Sci 10(49):1-36. https://doi.org/10.1007/ s13201-019-1138-y

Nigerian Industrial Standard (NIS) (2015) Nigerian Standard for Drinking Water Quality. https://africacheck.org/wpcontent/uploa ds/2018/06/Nigerian-Standard-for-Drinking-Water-Quality-NIS554-2015.pdf

Nouh EA, Lasheen TA, El-sherif RM, Abdel-Ghany NA (2019) $\mathrm{CeO}_{2}-$ $\mathrm{TiFe}_{2} \mathrm{O}_{4}$ nanocomposite for efective removal of uranium ions from aqueous waste solutions. Springer Nature Appl Sci 1(159):1-13

Oh WD, Wong Z, Chen X, Lin KYA, Veksha A, Lisak G, Lim TT (2020) Enhanced activation of peroxydisulfate by $\mathrm{CuO}$ decorated on hexagonal boron nitride for bisphenol a removal. Chem Eng J. https://doi.org/10.1016/j.cej.2020.124714

Ojonimi T, Asuke F, Onimisi M, Onuh C (2019) Acid mine drainage (AMD): an environmental concern generated by coal mining. J Degr Mining Lands Manag 6:1875-1881. https://doi.org/ 10.15243/jdmlm.2019.064.1875

Ouyang D, Zhuo Y, Hu L, Zeng Q, Hu Y, He Z (2019) Research on the adsorption behavior of heavy metal ions by porous material prepared with silicate tailings. Minerals 9(291):1-16. https://doi. org $/ 10.3390 / \min 9050291$

Patidar V, Jain P (2017) Green synthesis of $\mathrm{TiO} 2$ nanoparticle using moringa oleifera leaf extract. Int Res J Eng Technol 4(3):1-4

Pavesi T, Moreira JC (2020) Mechanisms and individuality in chromium toxicity in humans. J Appl Toxicol 40:1183-1197. https:// doi.org/10.1002/jat.3965

Pietrelli L, Ippolito NM, Ferro S, Dovì VG, Vocciante M (2019) Removal of Mn and as from drinking water by red mud and pyrolusite. J Environ Manag 237:526-533. https://doi.org/10.1016/j. jenvman.2019.02.093

Prasse C, Stalter D, Schulte-Oehlmann U, Oehlmann J, Ternes T (2015) Spoilt for choice: a critical review on the chemical and biological assessment of current wastewater treatment technologies. Water Res 87:237-270

Redha A, Al-Hasan R, Afzal M (2021) Synergistic and concentration-dependent toxicity of multiple heavy metals compared with single heavy metals in conocarpus lancifolius. Environ Sci Pollut Res 28(18):23258-23272. https://doi.org/10.1007/ s11356-020-12271-0

Rodríguez-Padrón D, Puente-Santiago AR, Luna-Lama F, Caballero AL, Muñoz-Batista MJ, Luque R (2019) Versatile protein-templated $\mathrm{TiO}_{2}$ nanocomposite for energy storage and catalytic applications. ACS Sustain Chem Eng 7(5):5329-5337

Rudi NN, Muhamad MS, Chuan LT, Alipal J, Omar S, Hamidon N, Harun $\mathrm{H}$ (2020) Evolution of adsorption process for manganese removal in water via agricultural waste adsorbents. Heliyon. https://doi.org/10.1016/j.heliyon.2020.e05049

Saha S, Sinha A (2018) A review on treatment of acid mine drainage with waste materials: a novel approach. Global NEST J 20(3):512-528. https://doi.org/10.30955/gnj.002610

Sdiri AT, Higashi T, Jamoussi F (2014) Adsorption of copper and zinc onto natural clay in single and binary systems. Int $\mathrm{J}$ Environ Sci Technol 11:1081-1092. https://doi.org/10.1007/ s13762-013-0305-1

Seo EY, Cheong YW, Yimb GJ, Mina KW, Geroni JW (2016) Recovery of $\mathrm{Fe}, \mathrm{Al}$ and $\mathrm{Mn}$ in acid coal mine drainage by sequential selective precipitation with control of $\mathrm{pH}$. CATENA 148:11-16. https://doi.org/10.1016/j.catena.2016.07.022

Shukla SK, Mushaiqri NR, Subhi HMA, Yoo K, Sadeq HA (2020) Low-cost activated carbon production from organic waste and its utilization for wastewater treatment. Appl Water Sci. https://doi. org/10.1007/s13201-020-1145-Z

Siddiqui SI, Chaudhry SA (2017) Iron oxide and its modified forms as an adsorbent for arsenic removal: a comprehensive recent

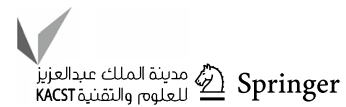


advancement. Process Saf Environ Prot 111:592-626. https://doi. org/10.1016/j.psep.2017.08.009

Soni M, Mehta P, Soni A, Goswami GK (2018) Green nanoparticles: synthesis and applications. J Biotechnol Biochem 4(3):78-83. https://doi.org/10.9790/264X-0403017883

Subhapriya S, Gomathipriya P (2018) Green synthesis of titanium dioxide (TiO2) nanoparticles by Trigonella foenum-graecum extract and its antimicrobial properties. Microb Pathog 116:215220. https://doi.org/10.1016/j.micpath.2018.01.027

Subhi HA, Adeeb MS, Pandey M, Sadeq HA, Kumar D, Shukla SK (2020) Effect of different activation agents on the pollution removal efficiency of date seed activated carbon: process optimization using response surface methodology. Appl Water Sci 10(166):1-9. https://doi.org/10.1007/s13201-020-01251-x

Swathi N, Sandhiya D, Rajeshkumar S, Lakshmi T (2019) Green synthesis of titanium dioxide nanoparticles using Cassia fistula and its antibacterial activity. Int J Res Pharm Sci 10(2):856-860. https:// doi.org/10.26452/ijrps.v10i2.261

Tavlieva MP, Genieva SD, Georgieva VG, Vlaev LT (2015) Thermodynamics and kinetics of the removal of manganese(II) ions from aqueous solutions by white rice husk ash. J Mol Liq 211:938-947

Tijani JO, Momoh UO, Salau RB, Bankole MT, Abdulkareem AS, Roos WD (2019) Synthesis and characterization of $\mathrm{Ag}_{2} \mathrm{O} / \mathrm{B}_{2} \mathrm{O}_{3} /$ $\mathrm{TiO}_{2}$ ternary nanocomposites for photocatalytic mineralization of local dyeing wastewater under artificial and natural sunlight irradiation. Environ Sci Pollut Res. https://doi.org/10.1007/ s11356-019-05124-y

Wang Z, Bao J, Wang T, Moryani HT, Kang W, Zheng J, Xiao W (2021) Hazardous heavy metals accumulation and health risk assessment of different vegetable species in contaminated soils from a typical mining city. Central China 18(5):2617

World Health Organization (WHO) (2017) Guidelines for drinkingwater quality. Fourth Edition, Incorporating First Addendum, Volume 1 Recommendation, Geneva. ISBN: 9789241549950. http:// www.who.int/water_sanitation_health/dwq/fulltext.pdf

Xiang Q, Ma X, Zhang D, Zhou H, Liao Y, Zhang H, Bazaka K (2019) Interfacial modification of titanium dioxide to enhance photocatalytic efficiency towards $\mathrm{H}_{2}$ production. J Colloid Interface Sci 556:376-385

Xie Y, Lu G, Yang C, Qu L, Chen M, Guo C, Dang Z (2018) Mineralogical characteristics of sediments and heavy metal mobilization along a river watershed affected by acid mine drainage. PLoS ONE 13(1):1-17. https://doi.org/10.1371/journal.pone.0190010

Yang K, Liu Y, Li Y, Cao Z, Zhou C, Wang Z, Xu X (2019) Applications and characteristics of $\mathrm{Fe}-\mathrm{Mn}$ binary oxides for $\mathrm{Sb}(\mathrm{V})$ removal in textile wastewater: selective adsorption and the fixedbed column study. Chemosphere 232:254-263. https://doi.org/10. 1016/j.chemosphere.2019.05.194

Youssef HF, Hegazy WH, Abo-almaged HH, El-Bassyouni GT (2015) Novel synthesis method of micronized Ti-zeolite Na-A and cytotoxic activity of its silver exchanged form. Bioinorg Chem Appl 2015:1-12. https://doi.org/10.1155/2015/428121

Yusof KN, Alias SS, Harun Z, Basri H, Azhar FH (2018) Parkia speciosa as reduction agent in green synthesis of silver nanoparticles. Chem Select 3:1-6

Zahir AA, Chauhan I, Bagavan A, Kamaraj C, Elango G, Shankar J, Singh N (2015) Green synthesis of silver and titanium dioxide nanoparticles using euphorbia prostrata. Antimicrob Agents Chemother 59(8):4782-4799

Zendelska A, Golomeova M, Golomeov B, Krstev B (2018) Effect of competing cations $(\mathrm{Cu}, \mathrm{Zn}, \mathrm{Mn}, \mathrm{Pb})$ adsorbed by Zeolite bearing Tuff from Macedonia. Nat Environ Pollut Technol 17(1):21-23

Zhao C, Ge R, Zhen Y, Wang Y, Li Z, Shi Y, Chen X (2019) A hybrid process of coprecipitation-induced crystallization-capacitive deionization-ion exchange process for heavy metals removal from hypersaline ternary precursor wastewater. Chem Eng J. https://doi. org/10.1016/j.cej.2019.122136

Publisher's Note Springer Nature remains neutral with regard to jurisdictional claims in published maps and institutional affiliations. 